\title{
Long-term visibility variation in Athens (1931-2013): a proxy for local and regional atmospheric aerosol loads
}

\author{
Dimitra Founda $^{1}$, Stelios Kazadzis ${ }^{2,1}$, Nikolaos Mihalopoulos ${ }^{1,3}$, Evangelos Gerasopoulos ${ }^{1}$, Maria Lianou ${ }^{1}$, and \\ Panagiotis I. Raptis ${ }^{1}$ \\ ${ }^{1}$ Institute for Environmental Research \& Sustainable Development, National Observatory of Athens, Athens, Greece \\ ${ }^{2}$ Physikalisch-Meteorologisches Observatorium Davos, World Radiation Center, Davos, Switzerland \\ ${ }^{3}$ Department of Chemistry, University of Crete, Heraklion, Greece \\ Correspondence to: Dimitra Founda (founda@noa.gr)
}

Received: 16 December 2015 - Published in Atmos. Chem. Phys. Discuss.: 21 March 2016

Revised: 16 July 2016 - Accepted: 26 July 2016 - Published: 12 September 2016

\begin{abstract}
This study explores the interdecadal variability and trends of surface horizontal visibility at the urban area of Athens from 1931 to 2013, using the historical archives of the National Observatory of Athens (NOA). A prominent deterioration of visibility in the city was detected, with the long-term linear trend amounting to $-2.8 \mathrm{~km} \mathrm{decade}^{-1}(p<$ 0.001 ), over the entire study period. This was not accompanied by any significant trend in relative humidity or precipitation over the same period. A slight recovery of visibility levels seems to be established in the recent decade (2004$2013)$. It was found that very good visibility $(>20 \mathrm{~km}) \mathrm{oc}-$ curred at a frequency of $34 \%$ before the $1950 \mathrm{~s}$, while this percentage drops to just $2 \%$ during the decade 2004-2013. The rapid impairment of the visual air quality in Athens around the 1950s points to the increased levels of air pollution on a local and/or regional scale, related to high urbanization rates and/or increased anthropogenic emissions on a global scale at that period. Visibility was found to be negatively/positively correlated with relative humidity/wind speed, the correlation being statistically valid at certain periods. Wind regime and mainly wind direction and corresponding air mass origin were found to highly control visibility levels in Athens. The comparison of visibility variation in Athens and at a non-urban reference site on Crete island revealed similar negative trends over the common period of observations. This suggests that apart local sources, visibility in Athens is highly determined by aerosol load of regional origin. AVHRR and MODIS satellite-derived aerosol optical depth (AOD) retrievals over Athens and surface measure-
\end{abstract}

ments of $\mathrm{PM}_{10}$ confirmed the relation of visibility to aerosol load.

\section{Introduction}

Visibility is defined as the greatest distance at which a black object of suitable dimensions (located on the ground) can be seen and recognized, when observed against the horizon sky during daylight (WMO, 1992). Visibility represents one of the dominant features of the climate and landscape of an area. Although it is highly affected by atmospheric circulation and the prevailing meteorological conditions, under clear sky conditions it is mainly determined by the loading in atmospheric aerosols (Davis, 1991; Lee, 1994; van Beelen and van Delden, 2012; Doyle and Dorling, 2002; Singh and Dey, 2012); therefore, visibility can be considered as a strong indicator of air quality over an area. Horizontal visibility has also been introduced in formulas for the estimation of atmospheric turbidity parameters (e.g., in the Ångström atmospheric turbidity coefficients; Eltbaakh et al., 2012).

Aerosols in the atmosphere contribute to light extinction by scattering and absorbing, thus reducing visibility (Appel et al., 1985; Chan et al., 1999; Elias et al., 2009; Singh and Dey, 2012). The impact of particulate matter (PM) on visibility depends on its physical (e.g., particle size distribution) and chemical properties (Dayan and Levy, 2005). In particular, visibility is inversely related to light extinction coefficient, which is determined by scattering and absorption of light by gases and particles, the latter (e.g., sulfate- 
and carbon-containing particles) being the main contributor (Malm, 1999; Hand et al., 2002; Bäumer et al., 2008; Deng et al., 2011; Wang et al., 2012). Sulfate- and carbon-containing particles play a major role in light extinction, while the role of relative humidity $(\mathrm{RH})$ on visibility is also important (Larson and Cass, 1989; Malm, 1999) because when RH reaches saturation values, visibility deteriorates due to fog formation and the hygroscopic growth of $\mathrm{SO}_{4}^{2-}, \mathrm{NH}_{4}^{+}$and $\mathrm{NO}_{3}^{-}$particles (Tang, 1996; Singh and Dey, 2012). At local and regional level, wind speed and direction are also very important factors, as they determine the transport and origin of air pollution.

Although the use of visibility as a viable atmospheric variable has been disputed by many researchers due to the numerous biases related to observational procedures (Davis, 1991), visibility statistics have been increasingly used as a surrogate for aerosol load (Zhao et al., 2011), especially since visibility records span quite long-term periods. Today, there is a large number of studies that use visibility observations to investigate the spatial and temporal variation of the optical properties of the atmosphere, mainly in relation to pollutant emissions and aerosol load. These studies refer to global, regional and local scales. On a global scale, a decrease of clear sky visibility over land from 1973 to 2007 is reported by Wang et al. (2009). This is interpreted in terms of aerosol concentration and its impact on incident solar irradiance. A significant decrease in visibility was observed over Asia, South America, Australia and Africa (1973-2007), while over Europe visibility increased after the 1980s as a result of air pollution mitigation measures. Vautard et al. (2009) found a significant decrease in the frequency of low-visibility days in Europe after the 1980s, which is spatially and temporally correlated with $\mathrm{SO}_{2}$ emissions. Stjern et al. (2011) reported that emissions reduction from 1983 to 2008 in the heavily industrialized area of central Europe (the formerly called Black Triangle, named after the triangle of the meeting borders of Germany, Poland and the Czech Republic) caused an increase in the horizontal visibility by $15 \mathrm{~km}$, in contrast to the clean area where visibility increased by only $2.5 \mathrm{~km}$. Doyle and Dorling (2002) observed significant improvement of visibility after the early 1970s at many sites in UK, attributed to anti-pollution measures, while van Beelen and van Delden (2012) found that the proportion of days with high visibility $(>19 \mathrm{~km}$ ) almost doubled since the early 1980s in the Netherlands. These findings for Europe are in line with the so called dimming/brightening periods, referring to observed decreasing/increasing trends of surface solar radiation, associated with relevant changes in anthropogenic emissions (e.g., Streets et al., 2006; Wild, 2009; Cermak et al., 2010; Folini and Wild, 2011; Nabat et al., 2014).

In contrast to European areas, a tendency towards lower visibility is observed in developing countries (e.g., China, South Korea, South Taiwan, India), where it is still difficult to control air pollution (Ghim et al., 2005; Che et al., 2007; Wan et al., 2011; Singh and Dey, 2012; Wu et al., 2012). Along this line, Wu et al. (2012) found strong correlation between aerosol optical depth (AOD) and visibility in China over the period 2000-2009 and an overall decreasing trend in visibility (under sunny conditions) during the last 50 years. Singh and Dey (2012) correlated visibility in Delhi with aerosols composition and reported a rapid decrease of visibility during 1980-2000 and stabilization afterwards.

Urban environments are of particular interest, as air pollution from local sources is superimposed on regional ones, strongly impacting visibility (Davis, 1991; Eidels-Dubovoi, 2002; Tsai et al., 2003, 2007; Dayan and Levy, 2005; Chang et al., 2009; Kim, 2015).

The present study explores the historical observations of visibility in Athens, which is the oldest time series of visibility in Greece and, to our knowledge, one of the oldest, uninterrupted time series of visibility in the Eastern Mediterranean. The records are retrieved from the historical climatic archives of the National Observatory of Athens (NOA) and span a period of more than 80 years (1931-2013). In the past, Carapiperis and Karapiperis (1952) reported on the correlation between the visibility and the blue color of the Attica sky, while Kanellopoulou (1979) analyzed visibility in Athens for the period 1931-1977 and reported a pronounced decrease after the 1950s. Since then, there has been no other study to address changes in visibility, as well as the factors behind these changes during the last 40 years, when significant changes occurred in Athens in terms of urban expansion, traffic load, 2004 Olympic Games construction and the economic recession (starting in 2008). The interdecadal variability and long-term trends of visibility in Athens are presented in the study. The role of meteorology and aerosol load (of local and regional origin) on the variability and trends of visibility is investigated and discussed, while the relationship between visibility and aerosol load is investigated through the analysis of satellite AOD retrievals over Athens as well as surface measurements of $\mathrm{PM}_{10}$ in Athens and Finokalia station (Crete) over shorter periods.

\section{Study area and data}

\subsection{Study area}

Athens, the capital of Greece, is the main center of commercial, financial, societal and cultural activities of the country. The Greater Athens Area (GAA) (Fig. 1) extends beyond the administrative municipal city limits and covers a surface of $433 \mathrm{~km}^{2}$. The population of GAA is approximately 3.7 million (almost twice the population of 1961) and accounts for more than one-third of the Greek population. The growth of the population was coupled with a significant increase in the number of vehicles. Specifically, the number of private cars rose from $2 \%$ of inhabitants in 1964 to $44 \%$ in 2008. The population growth and the increased number of automobiles have caused traffic problems, increased anthropogenic emis- 


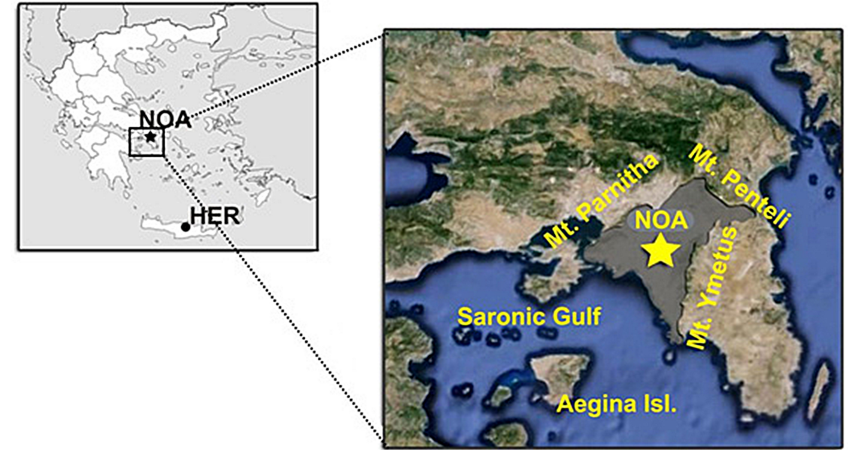

Figure 1. Map of the study area in Greece, including the Athens urban station (NOA) and the non-urban reference station (HER) at Heraklion airport, Crete. The grey surface in the colored map represents the boundary of the Greater Athens Area (GAA).

sions and degradation of air quality in the city. The complex topography, consisting of relatively high mountains around GAA (Fig. 1), induces poor ventilation of the city. Sea/land breezes appear along the NE-SW axis and play a dominant role in the accumulation of air pollutants (Kalabokas et al., 1999a, b).

In order to compare our findings for Athens with a remote reference site, the visibility records from the Heraklion airport (HER) in Crete Island were used (Fig. 1). Heraklion is located about $330 \mathrm{~km}$ south of Athens, while its airport is $5 \mathrm{~km}$ east of the city with no significant (or systematic) influence by the urban web.

\subsection{Climatic features of Athens}

Athens has a temperate climate with warm and dry summers and wet and mild winters, typical for the Eastern Mediterranean. Table 1 presents monthly and annual normal values along with standard deviations of the daily mean $\left(T_{\text {mean }}\right)$, maximum $\left(T_{\max }\right)$ and minimum $\left(T_{\min }\right)$ air temperature, precipitation amount and precipitation frequency (PF) (defined as the number of days with total precipitation $>1 \mathrm{~mm}$, following WMO), RH and wind speed in Athens, based on the WMO reference period, 1971-2000. July and August are the warmest and driest months of the year. The periods from May to September and from October to March represent the dry and wet periods of the year, respectively. Precipitation is sparse in summer (June-August), with the total amount averaging $20 \mathrm{~mm}$ and $\mathrm{PF}$ averaging 3 days. Athens receives on average approximately $400 \mathrm{~mm}$ of rain per year, corresponding to 43 rainy days (Table 1 ).

During summer, the area is dominated by anticyclonic circulation that enhances air temperature and intensifies the urban heat island. Athens has been experiencing a significant warming since the mid-1970s, more pronounced in summer, which is the additive result of regional warming and gradual intensification of the urban heat island (Founda, 2011;

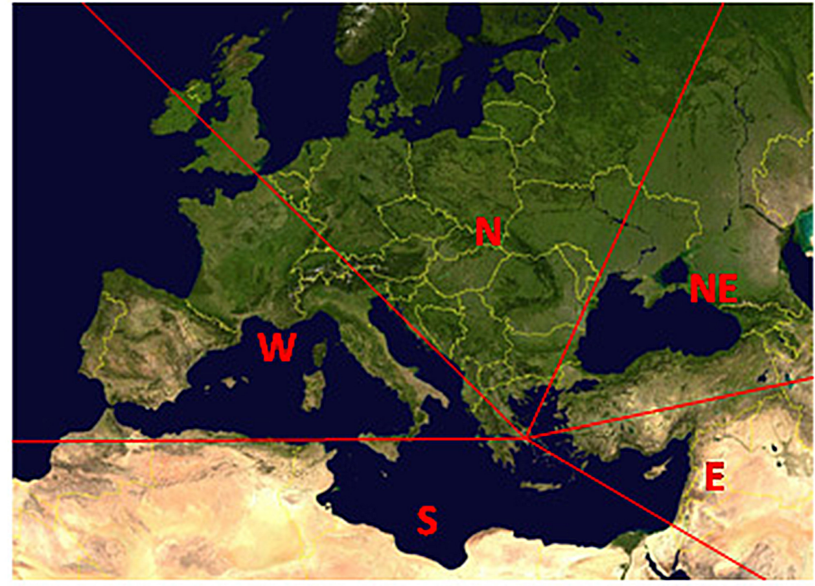

(a)

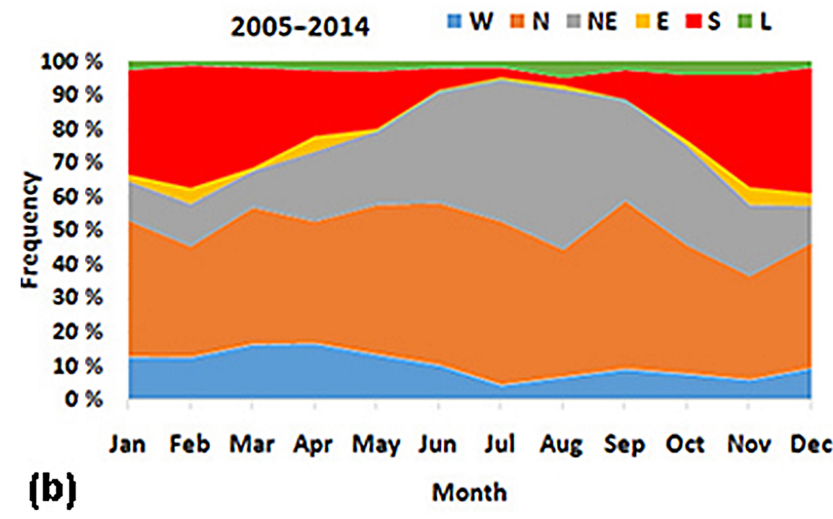

Figure 2. (a) Main sectors related to air mass origin in Athens. (b) Seasonal variability of the relative frequency of air mass origin in Athens, following the sectors defined in (a), averaged over the period 2005-2014. Category "L" refers to air masses of local origin.

Founda et al., 2015). Strong northeasterly winds in summer, known from antiquity as "etesians", induce a relief from air temperature and air pollution levels in the city.

Air mass origin was identified by applying a 4-day backtrajectory analysis, calculated daily at 12:00 UT with the Hybrid Single-Particle Lagrangian Integrated Trajectory (HYSPLIT) model (version 4.9; model data used for vertical motion) (Draxler et al., 2009). Figure 2a presents the main sectors related to air mass origin in Athens, based on a 10-year climatology (2005-2014) of daily air trajectories ending at $1000 \mathrm{~m}$ above ground level, while Fig. $2 \mathrm{~b}$ presents the seasonal variability of air mass origin according to the sectors defined in Fig. 2a. The $S$ (south) sector is linked to transport of air masses from arid areas of $\mathrm{N}$ Africa, frequently associated with dust events that affect the Eastern Mediterranean (Hamonou et al., 1999; Gkikas et al., 2016), the N (north) sector accounts for the Balkans and the main continental Europe, while the W (west) sector corresponds to SW Europe and the W Mediterranean Basin. Note that air mass 
Table 1. Mean monthly and yearly values with standard deviations of basic climatic elements in Athens (NOA), calculated from the WMO climatic period (1971-2000)*.

\begin{tabular}{lccccccc}
\hline Month & $\begin{array}{c}T_{\text {mean }} \\
\left({ }^{\circ} \mathrm{C}\right)\end{array}$ & $\begin{array}{c}T_{\max } \\
\left({ }^{\circ} \mathrm{C}\right)\end{array}$ & $\begin{array}{c}T_{\min } \\
\left({ }^{\circ} \mathrm{C}\right)\end{array}$ & $\begin{array}{c}\mathrm{RH} \\
(\%)\end{array}$ & $\begin{array}{c}\text { Precipitation } \\
(\mathrm{mm})\end{array}$ & $\begin{array}{c}\text { Number of rainy days } \\
(>1 \mathrm{~mm})\end{array}$ & $\begin{array}{c}\text { Wind Speed } \\
\left.(\mathrm{m} \mathrm{s})^{-1}\right)\end{array}$ \\
\hline January & $9.3 \pm 1.1$ & $13.0 \pm 1.3$ & $6.6 \pm 1.1$ & $72.1 \pm 3.9$ & $42.5 \pm 31$ & $5.6 \pm 3.0$ & $3.1 \pm 0.71$ \\
February & $9.6 \pm 1.4$ & $13.7 \pm 1.7$ & $6.8 \pm 1.4$ & $70.2 \pm 3.5$ & $44.8 \pm 29$ & $5.6 \pm 2.1$ & $3.4 \pm 0.50$ \\
March & $11.5 \pm 1.4$ & $16.1 \pm 1.8$ & $8.2 \pm 1.3$ & $67.6 \pm 4.3$ & $50.2 \pm 41$ & $5.4 \pm 2.6$ & $3.3 \pm 0.72$ \\
April & $15.4 \pm 1.3$ & $20.5 \pm 1.6$ & $11.5 \pm 1.1$ & $62.7 \pm 4.6$ & $32.7 \pm 29$ & $4.2 \pm 2.6$ & $2.8 \pm 0.51$ \\
May & $20.3 \pm 1.1$ & $25.7 \pm 1.3$ & $16.1 \pm 1.1$ & $57.3 \pm 4.0$ & $16.7 \pm 16$ & $2.6 \pm 1.9$ & $2.9 \pm 0.45$ \\
June & $25.0 \pm 0.9$ & $30.6 \pm 1.2$ & $20.4 \pm 0.9$ & $51.3 \pm 3.7$ & $7.5 \pm 10$ & $0.9 \pm 1.0$ & $3.1 \pm 0.60$ \\
July & $27.3 \pm 1.1$ & $33.1 \pm 1.4$ & $22.7 \pm 1.1$ & $48.5 \pm 4.2$ & $6.6 \pm 9$ & $0.9 \pm 1.1$ & $3.5 \pm 0.75$ \\
August & $26.8 \pm 1.2$ & $33.7 \pm 1.4$ & $22.5 \pm 1.2$ & $49.8 \pm 5.1$ & $7.2 \pm 12$ & $0.9 \pm 1.2$ & $3.5 \pm 0.58$ \\
September & $23.4 \pm 1.1$ & $29.2 \pm 1.5$ & $19.4 \pm 1.0$ & $57.0 \pm 4.7$ & $9.4 \pm 1$ & $1.3 \pm 1.6$ & $2.9 \pm 0.47$ \\
October & $18.5 \pm 1.5$ & $23.5 \pm 1.8$ & $15.1 \pm 1.6$ & $66.4 \pm 3.7$ & $42.9 \pm 40$ & $3.7 \pm 2.4$ & $2.9 \pm 0.74$ \\
November & $14.0 \pm 1.3$ & $18.1 \pm 1.5$ & $11.1 \pm 1.3$ & $72.7 \pm 3.8$ & $59.9 \pm 45$ & $7.9 \pm 3.8$ & $2.9 \pm 0.73$ \\
December & $10.8 \pm 1.4$ & $14.4 \pm 1.8$ & $8.2 \pm 1.3$ & $74.0 \pm 3.2$ & $62.6 \pm 34$ & $9.0 \pm 13.4$ & $3.0 \pm 0.56$ \\
\hline
\end{tabular}

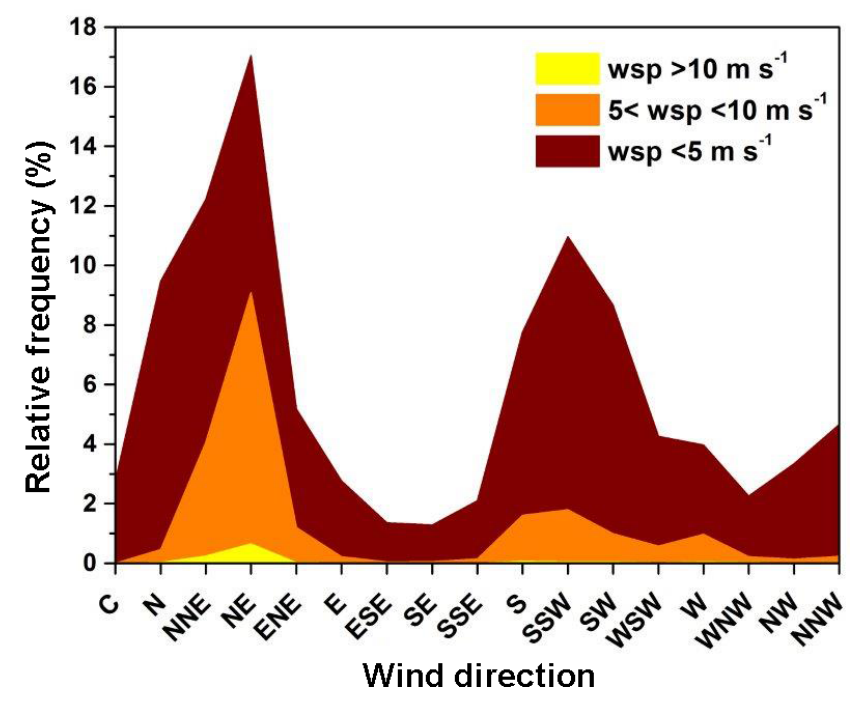

Figure 3. Relative frequencies of surface wind directions for three wind speed (wsp) categories at NOA, based on hourly values of the period 1971-2000. The integral of the upper curve is $100 \%$. For instance, the NE direction occurs cumulatively at a frequency of $17 \%$, which is the sum of $7.9 \%$ (wsp $<5 \mathrm{~m} \mathrm{~s}^{-1}$ ), $8.4 \%$ $\left(5<\mathrm{wsp}<10 \mathrm{~m} \mathrm{~s}^{-1}\right)$ and $0.7 \%\left(\mathrm{wsp}>10 \mathrm{~m} \mathrm{~s}^{-1}\right)$. The "C" sector corresponds to calms (wsp $\left.<0.3 \mathrm{~m} \mathrm{~s}^{-1}\right)$.

transport from the $\mathrm{W}$ sector is significantly blocked by the high-altitude mountain chain of Pindus $(>2500 \mathrm{~m})$, which expands from $\mathrm{N}$ to $\mathrm{S}$ along the western Greek mainland. On an annual basis, air masses from the $\mathrm{N}$ and $\mathrm{NE}$ sectors dominate, contributing by more than $60 \%$ and showing profound seasonal variability (maximum in summer).
Similar conclusions are drawn from surface wind measurements, reported in Fig. 3. Winds from N-NE directions prevail in Athens at a frequency of nearly $38 \%$ (Fig. 3). This sector is also associated with the occurrence of high wind speeds, as shown in the same figure. The secondmost-frequent surface winds correspond to S-SW directions $(27 \%)$. The frequency of occurrence of this sector is maximum during the intermediate seasons (spring and autumn) and is associated with the occurrence of dust events from $\mathrm{N}$ Africa and, in cases of light winds, with sea breezes from the Saronic Gulf (Fig. 1).

\subsection{Overview of air pollution in Athens}

A short introduction on the factors that diachronically control air pollution levels in Athens is presented here to facilitate the interpretation of visibility variations in terms of pollutants concentrations.

Air pollution in Athens has been systematically measured since the early 1970s. Road transport, domestic combustion and industrial activity have been the main sources of air pollution in GAA throughout the years. Downward trends of sulfur dioxide, black smoke, carbon monoxide and nitrogen oxides have been reported from the mid-1980s to the late 1990s, attributed to several anti-pollution measures adopted by the state (e.g., replacement of the old technology gasolinepowered private cars and the reduction of the sulfur content in diesel oil) (Kalabokas et al., 1999a). Negative trends of $\mathrm{NO}_{2}, \mathrm{NO}_{x}$ and $\mathrm{O}_{3}$ from the mid-1980s to 2009 are also reported in several urban stations (Mavroidis and Ilia, 2012).

Measurements of PM had only occasionally been conducted in Athens before the EU Directive (1999/30/EC) was launched, revealing increased concentrations of $\mathrm{PM}_{10}$ (Hoek 
et al., 1997). Chaloulakou et al. (2003) reported on $\mathrm{PM}_{10}$ and $\mathrm{PM}_{2.5}$ at a single road traffic sampling location from 1999 to 2000 and underlined the contribution of local emission sources, mostly traffic, to the high levels of PM concentration. Grivas et al. (2004) highlighted the significant vehicular contributions to $\mathrm{PM}_{10}$ concentrations in Athens during 20012004 and quantified the exceedances of the annual limit set by the EU Directive.

Studying the contribution of local sources vs. regional and the role of long-range transport over megacities of the Eastern Mediterranean, including GAA, Kanakidou et al. (2011) summarized that a significant number of PM exceedances registered in Athens is associated with regional pollution sources or natural dust transport, clearly highlighting the importance of regional transport processes. Theodosi et al. (2011) compared simultaneous mass and chemical composition measurements of size-segregated particulate matter $\left(\mathrm{PM}_{1}, \mathrm{PM}_{2.5}\right.$ and $\left.\mathrm{PM}_{10}\right)$ at two urban and a non-urban reference background site, concluding that during the warm season there is no significant (actually $<15 \%$ ) difference in $\mathrm{PM}_{1}$ between the urban and reference sites; in contrast, local anthropogenic sources dominate during the cold season. Regarding the coarse fraction, a significant contribution from soil was found in urban locations throughout the year, contributing significantly (up to $33 \%$ ) to the local $\mathrm{PM}_{10}$ mass.

Regarding columnar aerosol load and using ground-based AOD measurements in Athens, Gerasopoulos et al. (2011) showed that the greatest contribution (40\%) to the annually averaged AOD comes from regional sources (namely the Istanbul metropolitan area, the extended areas of biomass burning around the northern coast of the Black Sea, power plants spread throughout the Balkans and the industrial area in the Po Valley). Additional important contributors are dust from Africa ( $23 \%$ ), whereas the rest of Europe contributes another $22 \%$. Gkikas et al. (2016) found good correlation between $\mathrm{AOD}_{550 \mathrm{~nm}}$ and surface $\mathrm{PM}_{10}$ over the Mediterranean basin during desert dust episodes (2000-2013) and reported higher intensity but lower frequency of such episodes over the Central and Eastern Mediterranean. Additionally, Hatzianastassiou et al. (2009) found that local anthropogenic emissions in GAA contribute by $15-30 \%$ to the total AOD, as derived from satellite-based AOD measurements.

Vrekoussis et al. (2013) reported an improvement of air quality in Athens during the period 2008-2013 as a result of the economic recession and the subsequent reduction in vehicle use and industrial activity. For the same period, Paraskevopoulou et al. (2014) showed that the massive shift of Athens' population to wood burning for residential heating purposes gave rise to smog episodes characterized by high PM spikes during nighttime in winter. A longer-term (20082013) analysis of aerosol chemical composition and sources at a suburban site in Athens by Paraskevopoulou et al. (2015) revealed that the area of Athens is now generally dominated by aged, transported aerosols.

\subsection{Visibility observations in Athens}

The historical climatic record of the NOA was used in this study. NOA is located on the Hill of Nymphs $\left(37.97^{\circ} \mathrm{N}\right.$, $23.71^{\circ} \mathrm{E} ; 107 \mathrm{~m}$ above sea level), at the historical center of the city, near Acropolis. The location of the observations on the top of a hill ensures unobstructed view towards all directions. Visibility observations have been conducted uninterruptedly at NOA at least three times per day, since the late 1920s. Daily observations of visibility at 14:00 local standard time (LST, UT $+2 \mathrm{~h}$ ) from 1931 to 2013 were used in the study. The time series is complete, with a very short gap of 6 days occurring in December 1944 due to political convulsion in the country at that period.

Visibility data at other stations (e.g., Heraklion, Crete) were extracted from the network of the Hellenic National Meteorological Service (HNMS) and actually represent visibility observations at the airport station, initiated after the mid-1950s. Meteorological data for Athens over the period 1931-2013 were also acquired from the historical archives of NOA. Monthly, seasonal and annual mean values of visibility were derived from the daily observations at 14:00 LST.

An empirical scale of visibility classes, as recommended by the World Meteorological Organization (WMO), has been used for visibility observations at NOA (Table 2). Classes are defined based on the greatest distance at which a predefined object can be seen and recognized by the naked eye. The procedure requires that an operator scans the horizon for predetermined objects. In the case of Athens, some historical buildings in the city, as well as certain objects of the surrounding landscape that remained unaltered over the years (e.g., objects on the mountains or islands of the Saronic Gulf; Fig. 1), were chosen to represent visibility classes and relevant distance ranges. The procedure introduces inevitably some kind of subjectivity and bias in the measurements, related to individual eyesight of different operators. It is assumed, however, that the execution of visibility observations by different operators over the years could have possibly had a compensating effect and an overall reduction of biases. More details about the possible errors and validity of visibility observations have been thoroughly discussed by Davis (1991).

The use of the WMO scale introduces a further uncertainty to visibility observations, associated with the amplitude of visibility ranges corresponding to each visibility class. Information on the use of WMO scale and relative uncertainties, as well as the followed procedure for averaging daily visibility observations, is provided in the Supplement.

\subsection{Aerosol data used in the study}

Long time series of atmospheric pollution measurements in Athens and the selected reference site would enable drawing relationships between visibility and aerosols and would provide evidence for the origin (regional or local) of atmo- 
Table 2. The WMO empirical scale for visibility observations, used at NOA.

\begin{tabular}{llllllllll}
\hline Visibility classes & 1 & 2 & 3 & 4 & 5 & 6 & 7 & 8 & 9 \\
\hline Visibility ranges & $50-200 \mathrm{~m}$ & $200-500 \mathrm{~m}$ & $500-1000 \mathrm{~m}$ & $1-2 \mathrm{~km}$ & $2-4 \mathrm{~km}$ & $4-10 \mathrm{~km}$ & $10-20 \mathrm{~km}$ & $20-50 \mathrm{~km}$ & $>50 \mathrm{~km}$ \\
\hline
\end{tabular}

spheric pollution in Athens and its impact on long-term visibility variations. Given that such time series are missing, we used shorter time series of aerosol measurements for a direct comparison between visibility and atmospheric pollution in Athens.

In an effort to explore the relationship between visibility and AOD over Athens, we used the Terra/Modis AOD at $550 \mathrm{~nm}$, available since 2000. NASA's Terra satellite is sun synchronous and near polar-orbiting, with a circular orbit of $705 \mathrm{~km}$ above sea level. MODIS is capable of scanning 36 spectral bands across a $2330 \mathrm{~km}$ wide swath. MODIS aerosol products were used in order to analyze the temporal and spatial variability of aerosols over the wide area of interest. In this study, we used daily level-2 collection 5.1 MODIS/Terra AOD at $550 \mathrm{~nm}$. Daily overpass data for the specific area were extracted at a spatial resolution of $50 \times 50 \mathrm{~km}^{2}$. Previous studies have shown that such a spatial resolution product ensures sufficient daily measurements without losing out to the higher spatial resolution and hence provides a better opportunity of correctly viewing the atmospheric aerosol load (Ichoku et al., 2002). The overpass time is 09:35 $\pm 45 \mathrm{~min}$ UT.

In addition, in order to further examine long-term satellitebased AOD series in the area, we used the longest satellite time series available from the Advanced Very High Resolution Radiometer (AVHRR). AOD retrievals PATMOS$\mathrm{x}$ AVHRR level-2b channel $1(630 \mathrm{~nm})$ provide data over global oceans at high spatial resolution $\left(0.1^{\circ} \times 0.1^{\circ}\right)$, for one overpass per day. Data used were downloaded from NOAA Climate Data Record version 2 of aerosol optical thickness (Zhao et al., 2014) and cover the period from August 1981 to December 2009. Version 2 dataset has enhanced cloud screening and retrieves AOD only over non-glint water surface, which has less uncertainties of surface reflectance. AVHRR instrument was not designated for retrieving AOD, and thus its product embodies a large variety of uncertainties, including radiance calibration, systematic changes in single scattering albedo and ocean reflectance (Mishchenko et al., 2007). Current dataset radiances have been recalibrated using more accurate MODIS data (Chan et al., 2013). Smirnov et al. (2006) compared 38 days of shipborne measurements with a MICROTOPS-II, on a cruise in the Atlantic Ocean, to AVHRR AOD retrievals and found an average 0.05 overestimation of satellite data, with correlation coefficient equal to 0.95 . We used daily overpass data from the region around Athens $\left(37.5-38.2^{\circ} \mathrm{E}, 23.2-24.4^{\circ} \mathrm{N}\right)$ which included $72 \mathrm{ac}-$ tive (ocean) grid points. The above region was selected based on data availability on each grid within the distance of $70 \mathrm{~km}$ from the visibility observing site.

Surface $\mathrm{PM}_{10}$ measurements in Athens were also used to verify the relationship between visibility and particulate pollution from surface measurements. It is well known that desert dust plumes are often transported in altitude over the Mediterranean (e.g., Hamonou et al., 1999; Gkikas et al., 2015) and a portion of surface PM exceedances in Athens is associated with natural dust transport (Kanakidou et al., 2011). The analysis was based on a short dataset of $\mathrm{PM}_{10}$ at two stations in Athens (Aristotelous and Maroussi), covering the period 2008-2012. Aristotelous is an urban street station in the center of the city and Maroussi is a suburban station at a distance of about $15 \mathrm{~km}$ to the north of NOA.

Finally, a dataset of $\mathrm{PM}_{10}$ measurements at a reference station in Crete (Finokalia station), covering the period 20052014, was used for the detection of any trends, representative of regional atmospheric pollution trends. The Finokalia station $\left(35.24^{\circ} \mathrm{N}, 25.60^{\circ} \mathrm{E}\right)$ is located at the northern coast of Crete (Greece), at a distance of approximately $320 \mathrm{~km}$ to the south of Athens. There is no significant human activity within an area of nearly $15 \mathrm{~km}$ around the station, mainly characterized by scarce vegetation. The closest large urban area is the city of Heraklion (see map. of Fig. 1), with 150000 inhabitants, and located $50 \mathrm{~km}$ west of Finokalia. Aerosols at the site are mainly transported from southeastern Europe and $\mathrm{N}$ Africa and to a lesser extent from central and western Europe (Kouvarakis et al., 2000).

\section{Results}

\subsection{Interdecadal variation and trends in visibility}

Figure 4 displays the long-term development of the annual visibility in Athens from 1931 to 2013 . The population growth in the city of Athens over the same period is also shown, while the figure also displays the long-term variability of the RH in Athens (which is discussed below). It is obvious that the annual visibility in Athens has undergone a very strong and almost continuous decline over the past 80 years, in coincidence with the increase in population. The long-term linear trend over the entire study period was found to be equal to $-0.28 \mathrm{~km}_{\text {year }}{ }^{-1}$ (or $-2.8 \mathrm{~km}$ decade $^{-1}$, $p<0.001$ ). However, this trend is not constant throughout the entire study period. The following three subperiods, corresponding to different trends, are visually discerned in Fig. 4 (also confirmed by statistical sensitivity tests): (a) 19311948, (b) 1949-2003 and (c) 2004-2013. Visibility levels 


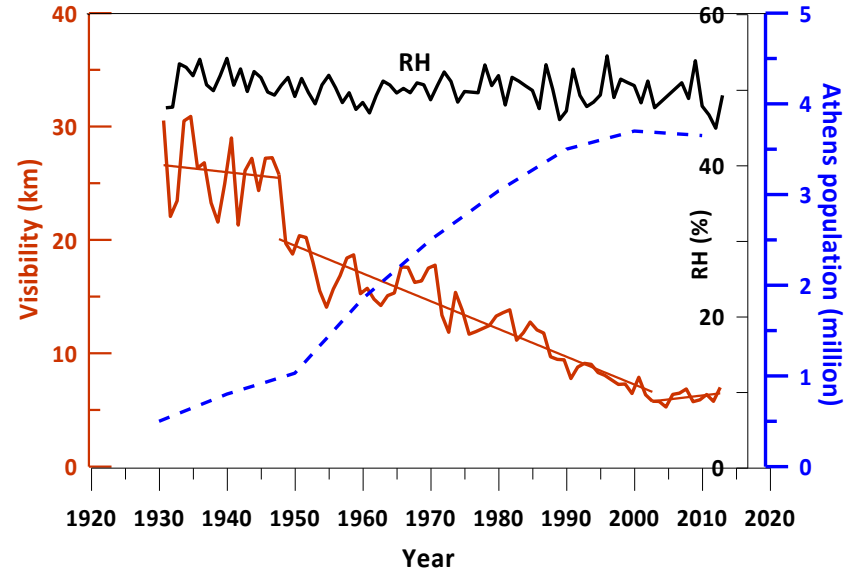

Figure 4. Interdecadal variability of the annual visibility in Athens from 1931 to 2013, along with linear trends for three subperiods: 1931-1948, 1949-2003 and 2004-2013 (red line). The dashed blue line illustrates the population growth in Athens (in millions) since 1930 (Founda, 2011). The long-term variability of the annual relative humidity (RH) in Athens is also shown (upper black line).

are remarkably higher in the first subperiod, varying around $25 \mathrm{~km}$. A slight negative trend is observed during this period $\left(-0.07 \mathrm{~km}\right.$ year $\left.^{-1}\right)$. In the late $1940 \mathrm{~s}$, visibility experienced a striking and abrupt decrease at the time of the first population burst, which was then followed by a progressive deterioration, at least until the early 2000s. In this second subperiod (1949-2003) visibility decreases at a rate of $-0.23 \mathrm{~km}$ year $^{-1}$ (or $-2.3 \mathrm{~km} \mathrm{decade}^{-1}, p<0.001$ ). A tendency of stabilization or even recovery seems to be established during the more recent decade 2004-2013, when visibility exhibits a slight increasing trend $\left(+0.07 \mathrm{~km} \mathrm{year}^{-1}\right)$. A detailed discussion on the observed trends and their links to air pollution is presented in Sect. 3.5. It is also noticeable that the year-to-year fluctuations of visibility decrease with decreasing visibility (Fig. 4) as a result of the very different resolutions of the visibility classes at high and low visibility (Table 2).

\subsection{Frequency distribution of visibility ranges}

The separation of the time series into three subperiods, as described above, follows changing trends. In the following, the much longer middle subperiod (1949-2003) was further separated into two parts (1949-1975 and 1976-2003), as it corresponds to substantially different visibility conditions. Figure 5 illustrates the frequency distribution of the different visibility ranges (as described in Table 2) for those four different subperiods.

In the first subperiod (1931-1948), visibility values are almost equally distributed between the ranges of $10-20 \mathrm{~km}$ and $20-50 \mathrm{~km}$, at frequencies of approximately $35 \%$. Very high visibility $(>50 \mathrm{~km})$ accounts for a considerable portion

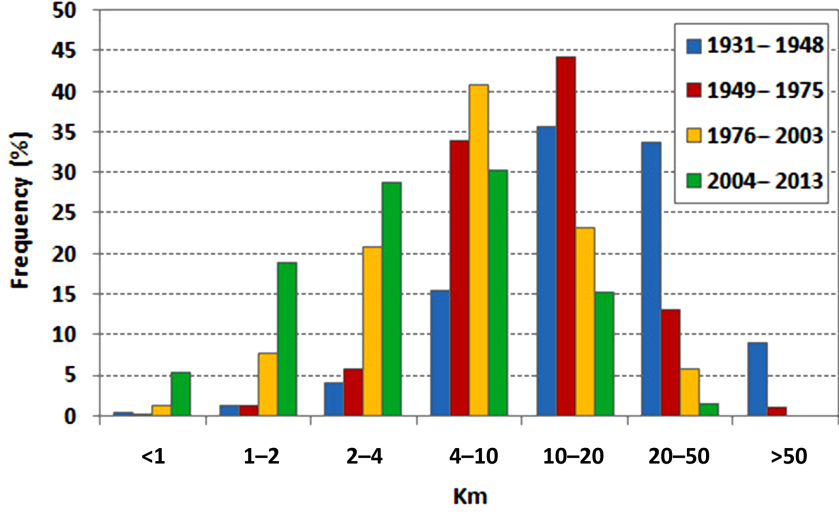

Figure 5. Relative frequency distribution of different visibility ranges (as defined in Table 2) in Athens for the four subperiods 1931-1948, 1949-1975, 1976-2003 and 2004-2013.

( $\sim 9 \%)$ of this subperiod and poor visibility $(<2 \mathrm{~km})$ corresponds cumulatively to only $2 \%$. The frequency of visibility lower than $1 \mathrm{~km}$ is very low $(0.4 \%)$, while visibility lower than $500 \mathrm{~m}$ occurred only in nine cases. Cumulatively, visibility exceeded $10 \mathrm{~km}$ at a frequency of approximately $80 \%$ during this period.

A progressive shift of frequency distribution towards lower visibility categories is observed in the next subperiods. In particular, the frequency of very good visibility $(20-50 \mathrm{~km})$ drops to 13 and $6 \%$ for the periods $1949-1975$ and 1976-2003, respectively, while the most frequent visibility range is $10-20 \mathrm{~km} \mathrm{(44 \% )} \mathrm{during} \mathrm{1949-1975} \mathrm{and} \mathrm{4-}$ $10 \mathrm{~km}(41 \%)$ during 1976-2003. The frequency of visibility $>50 \mathrm{~km}$ is almost negligible ( $\sim 1 \%$ during 1949-1975) and the frequency of poor visibility $(<2 \mathrm{~km})$ amounts cumulatively to $9 \%$ and $\sim 1 \%$ for $1949-1975$ and 1976-2003, respectively. Visibility lower than $500 \mathrm{~m}$ was observed only in two cases during 1949-1975 and in 10 cases during 19762003. Cumulatively, the percentage of days with visibility exceeding $10 \mathrm{~km}$ drops to 58 and $29 \%$ for the periods 1949 1975 and 1976-2003, respectively.

The frequency distribution changes dramatically during the most recent period (2004-2013). In particular, although visibility range of 4-10 km remains the most frequent (30\%), as in the subperiod 1976-2003, almost similar frequency $(\sim 28 \%)$ is also observed in the range of $2-4 \mathrm{~km}$. The frequency of poor visibility $(<2 \mathrm{~km})$ rises to approximately $25 \%$, with a substantial percentage $(5.6 \%)$ accounting for visibility lower than $1 \mathrm{~km}$ and $0.46 \%$ lower than $500 \mathrm{~m}$. Overall, visibility did not exceed $4 \mathrm{~km}$ for half of the days of the year during 2004-2013. The percentage of days with visibility $>10 \mathrm{~km}$ is $18 \%$, while the frequency of very good visibility ( $>20 \mathrm{~km}$ ) amounts to just $2 \%$. No case of visibility $>50 \mathrm{~km}$ was observed in this last subperiod. 

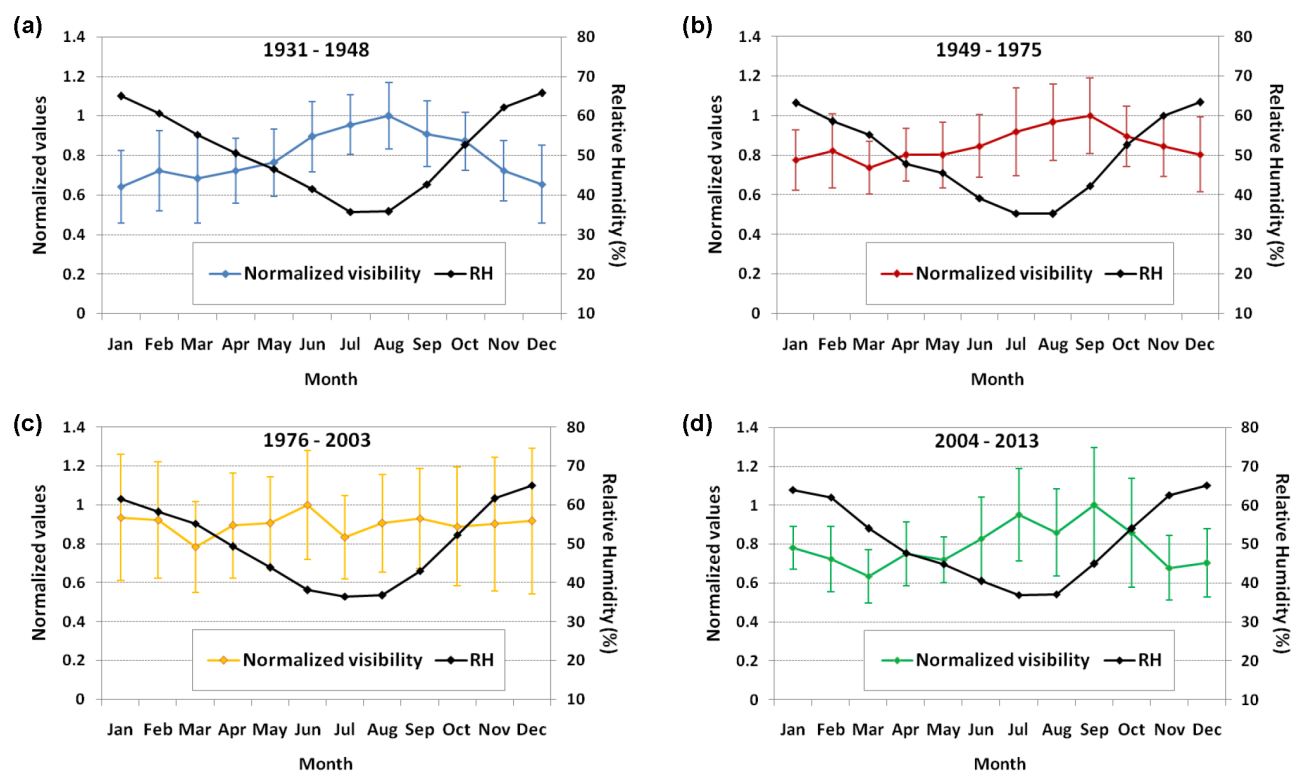

Figure 6. (a-d) Normalized mean monthly values of visibility in Athens for the subperiods (a) 1931-1948, (b) 1949-1975, (c) 1976-2003 and (d) 2004-2013, along with mean monthly values of relative humidity (RH) for each subperiod. Vertical lines represent standard deviations of mean monthly values of visibility.

\subsection{Seasonal variation of visibility}

Since visibility is influenced by the prevailing meteorological conditions (Davis, 1991; Sloane, 1982), it is expected to exhibit a seasonal variability, depending on the intra-annual variability of climatic conditions at the study area. Mean monthly values of visibility were calculated for the subperiods 1931-1948, 1949-1975, 1976-2003 and 2004-2013. Figure $6 \mathrm{a}-\mathrm{d}$ present the mean monthly values of visibility in Athens over each subperiod, normalized with the value of the month with the highest visibility. In the same plot, the mean monthly values of RH coinciding visibility observations at 14:00 LST over each subperiod are also shown. It is noteworthy that RH at NOA does not exhibit any significant trend over the years (as already shown in Fig. 4) and its monthly distribution remains almost unaltered in all subperiods. As one can see from Fig. 6a-d, visibility exhibits a seasonal cycle in all subperiods, with better visibility occurring in the warm and dry months of the year. Although seasonality is observed in all subperiods, the pattern is more evident and robust in the first subperiod (Fig. 6a), with much higher visibility values (up to $40 \%$ ) in the warm and dry months. The pattern of visibility in this period is almost a mirror image of the pattern of RH and reflects the influence of $\mathrm{RH}$ on visibility and the anti-correlation between these two variables. The lowest values of RH correspond to July and August (mean value of $\mathrm{RH} \sim 35 \%$ at 14:00 LST) and this probably results in visibility improvement. Moreover, strong northeasterly winds that prevail in eastern Greece during these months enhance ventilation and induce drier conditions in the city, therefore improving visibility.
The distinct seasonal cycle in the visibility of the first subperiod changed in the following subperiods (Fig. 6b-d). Although the warm and drier months always correspond to higher visibility levels, seasonality is noticeably attenuated and visibility differences between the warm and cold period are much lower. This possibly implies a weakening of the influence of meteorological conditions, as a result of (or in combination with) the stronger effect of air pollution on the visual air quality of the city.

The minimum of visibility is constantly observed in March during all subperiods. Indeed, March is a month in the transitional season and thus bears higher values of $\mathrm{RH}$ compared to summer months (mean RH at 14:00 LST $>50 \%$ and mean daily RH $\sim 67 \%$ in March). Additionally, March is a month in the growing season, with enhanced pollen and biogenic aerosol emissions, which is a known factor for visibility impairment (e.g., Kim, 2007). Increased frequency of dust outbreaks from N Africa in spring influence extensively the area of Eastern Mediterranean (Hamonou et al., 1999; Gerasopoulos et al., 2005, 2011; Gkikas et al., 2016) and thus constitute a major factor for visibility impairment during spring months. Léon et al. (1999) reported that $40 \%$ of the days with high aerosol optical depth at $865 \mathrm{~nm}$ $\left(\mathrm{AOD}_{865 \mathrm{~nm}}>0.18\right)$ over Thessaloniki (Greece) were associated with African dust transport events, all observed in the period March-July, while Dayan and Levy (2005) found higher $\mathrm{PM}_{10}$ values and lower visibility levels during spring in Tel Aviv (Israel), associated with the frequent passage of cyclones that cause natural dust outbreaks. 


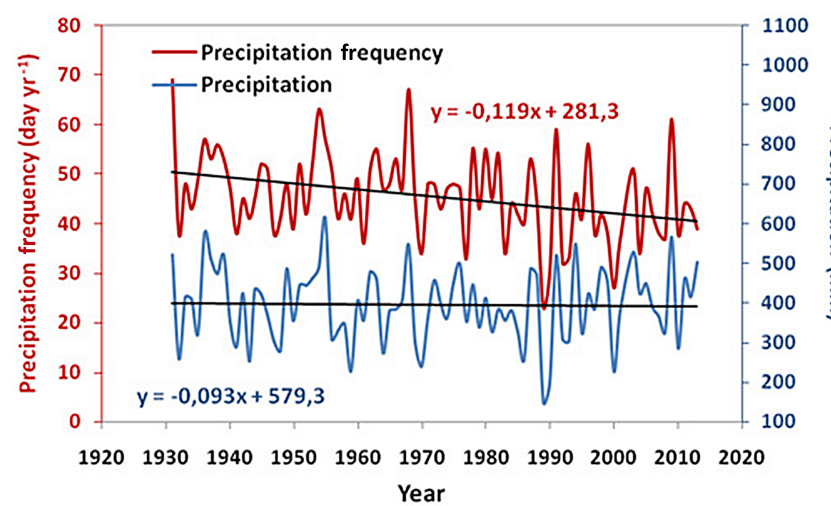

Figure 7. Long-term variability and linear trends of the annual precipitation amount and precipitation frequency (number of days year $^{-1}$ with precipitation $>1 \mathrm{~mm}$ ) at NOA, over the period 1931-2013. Slopes of linear trends are also shown.

\subsection{Visibility and meteorological conditions}

The impact of meteorological conditions on visibility has been investigated by different researchers using different approaches, as for instance the classification of synoptic circulation patterns (Sloane, 1982; Davis, 1991; Dayan and Levy, 2005), the application of correction factors on extinction coefficient to account for RH effect (Che et al., 2007), the estimation of correlation coefficients between visibility and meteorological variables (Deng et al., 2011) or simply the comparison of diurnal/seasonal cycles and temporal trends of visibility with the relevant cycles and trends of meteorological variables (van Beelen and van Delden, 2012). Sloane (1982) reported that periods with exceptionally maxima or minima of visual air quality were related (apart from sulfate emissions) to favorable synoptic circulation patterns. Studying visibility in Tel Aviv, Dayan and Levy (2005) reported a strong dependence of visibility levels on meteorological conditions, synoptic weather patterns and air mass origin, with the highest mean values occurring in summer, related to the persistent nature of the summer synoptic weather patterns in the Eastern Mediterranean. Deng et al. (2011) found that RH and wind speed were significantly correlated with visibility at an urban area of China, while Ghim et al. (2006) showed a considerable decrease in visibility in South Korea, despite the observed simultaneous decrease in RH levels. The relationship and possible impact of different meteorological parameters such as precipitation, $\mathrm{RH}$, wind speed and wind direction on visibility in Athens is discussed below.

\subsubsection{Visibility and precipitation}

Precipitation is associated with scavenging of atmospheric particles (e.g., Remoudaki et al., 1991a, b), possibly resulting in improvement of visibility. The PF in particular was found to control seasonal variability of the total atmospheric deposition of lead in the western Mediterranean (Remoudaki

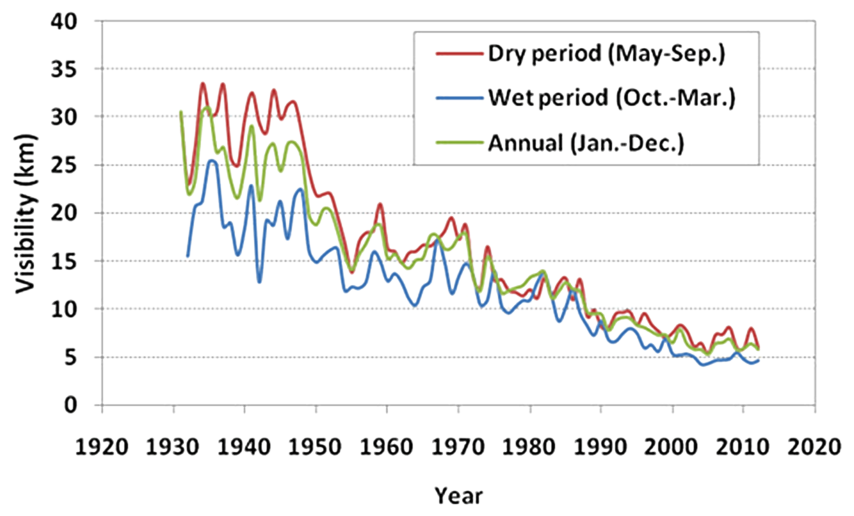

Figure 8. Variation of visibility at NOA from 1931-2013 during the dry (May-September), wet (October-March) and all year (JanuaryDecember) period.

et al., 1991b). Rainy days, in contrast, are associated with increased $\mathrm{RH}$, resulting in reduction of visibility. A plot illustrating the long-term variability of the annual precipitation amount and PF at NOA from 1931 to 2013 was created, for the detection of any significant trends (Fig. 7). As can be seen in the figure, no long-term trend is observed in the annual precipitation at NOA from 1931 to 2013, which could have had an effect on long-term trends in visibility. Precipitation frequency, in contrast, exhibits an overall negative trend over the same period $\left(-1.1\right.$ day decade $\left.^{-1}\right)$, which is not constant throughout the time series. Specifically, PF decreases from the late 1960s to the late 1980s, while it presents an increasing tendency after $1990\left(+1.3\right.$ day decade $\left.^{-1}\right)$. The correlation coefficient between annual visibility and PF was found to be positive only during the period from the early 1970 s to the late 1980s $(+0.45, p<0.05)$. A negative correlation coefficient was found in the post-1990 period $(-0.21)$ that was not statistically significant.

Subsets of data were also produced for the creation of additional visibility time series, accounting for precipitation influence. Figure 8 presents visibility variability during the wet (October-March) and dry (May-September) periods of the year, along with the annual values. Lower values during the rainy and cold period of the year are most probably associated with higher values of RH, resulting in the reduction of visibility. Despite the differences between the time series in Fig. 8, the overall tendency is similar, thus not affecting the validity of our conclusions regarding the long-term visibility impairment in Athens. Additional plots, created from subsets of "rain" and "no rain" days, are provided in the Supplement (Fig. S4).

\subsubsection{Correlation between visibility and other meteorological parameters (RH, wind)}

Figure 9 presents the running correlation coefficient (15-year window) between visibility and relative humidity and visi- 


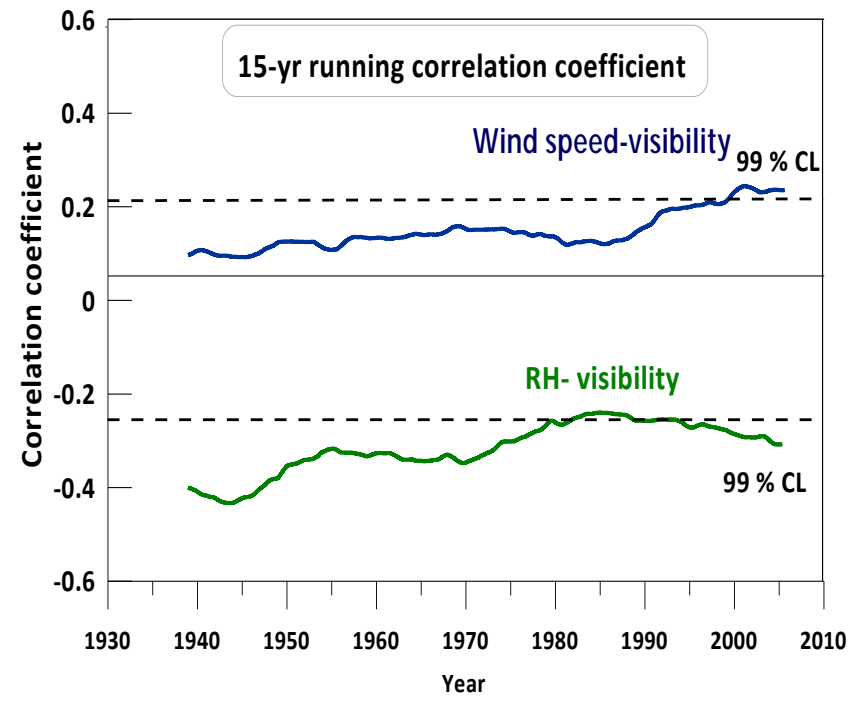

Figure 9. Running correlation coefficient and $99 \%$ confidence levels (CL; dashed lines) between visibility and wind speed (blue line) and visibility and RH (green line) in Athens, over the period 19312013. A 15-year window was used.

bility and surface wind speed at NOA, over the period 19312013. As expected, the correlation coefficient between visibility and RH is negative, indicating the anti-correlation between these two variables. High RH enhances water uptake by airborne particles, leading to higher light scattering and, thus, visibility impairment. Actually, when RH exceeds a threshold level (e.g., > 70\%), some inorganic salts, such as ammonium, sulfate and nitrate, undergo sudden phase transitions from solid particles to solution droplets and become responsible for visibility impairment, as compared to other particles that do not uptake water (Malm, 1999).

Following Fig. 9, the negative correlation between RH and visibility is statistically significant at the $99 \%$ confidence level almost over the entire study period. However, a progressive weakening of the correlation coefficient with time is observed, indicating a less strong correlation between the two variables over the years from the beginning. Stronger anticorrelation is found until the early 1970s, followed by lower (still significant) values until the mid-1990s. The progressive weakening of the correlation between RH and visibility in Athens possibly suggests a progressive weakening or mask of RH influence on visibility compared to the effect of other factors such as atmospheric pollution (although the influence of RH is enhanced by the presence of certain hygroscopic particles).

On the contrary, the impact of surface wind speed on visibility seems to be stronger during the late part of the time series (Fig. 9). Higher wind speeds in this case (positive correlation) are related to the more efficient city ventilation and dispersion of air pollutants, resulting in visibility improvement. In other cases, wind speed is also used as a proxy for

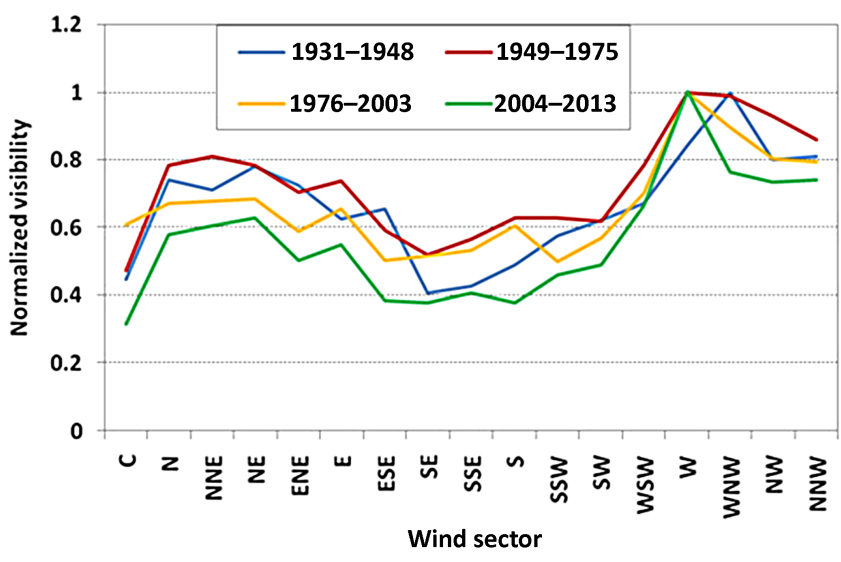

Figure 10. Variation of visibility with wind direction (sectors) over the subperiods 1931-1948, 1949-1975, 1976-2003 and 20042013. Visibility is normalized by its maximum value at a certain sector for each subperiod. Sector "C" corresponds to calms (wind speed $<0.3 \mathrm{~m} \mathrm{~s}^{-1}$ ). Frequency of each sector approximates closely its climatic value (Fig. 3 ) in all subperiods.

long-range transport, but then a negative correlation would be expected. Lower values of the coefficient in the early part of the time series possibly demonstrate that the lack of pollutants at that period detracts from the importance of ventilation. The correlation coefficient increases progressively over the years. The rate of increase is higher after the mid1980 s, when correlation becomes statistically significant at the $99 \%$ confidence level. Similar values of correlation coefficient $(\sim 0.29)$ between light extinction coefficient and wind speed are reported over Nanjing (China) by Deng et al. (2011).

Apart from wind speed, visibility was also found to be sensitive to wind direction. A distinct variability of visibility with wind direction is observed in Fig. 10, for all subperiods. Lower values of visibility are related to southerly winds, as they bring either dust from Sahara or warmer and more humid air masses from the sea (see also Figs. 1, 2b). Southeasterly winds are, in general, weak winds (see Fig. 3), while southwesterly winds are associated with sea breezes from the Saronic Gulf (Fig. 1). In general, sea breezes and calm wind conditions favor the accumulation of pollutants and the formation of secondary aerosols and photochemical smog in Athens (Colbeck et al., 2002), thus reducing visibility. A number of S/SW events are also associated with strong wind speeds occurring during Sahara dust outbreaks, which enrich Athens atmosphere with dust particles that decrease visibility (Figs. 2, 3). As one can see from Fig. 10, the highest visibility occurs under northwesterly winds and this is robust for all subperiods. One explanation is that air masses originated from northwesterly directions are much drier as they have lost water vapor after passing over the high mountainous basin of the Greek mainland (e.g., Pindus mountain), 


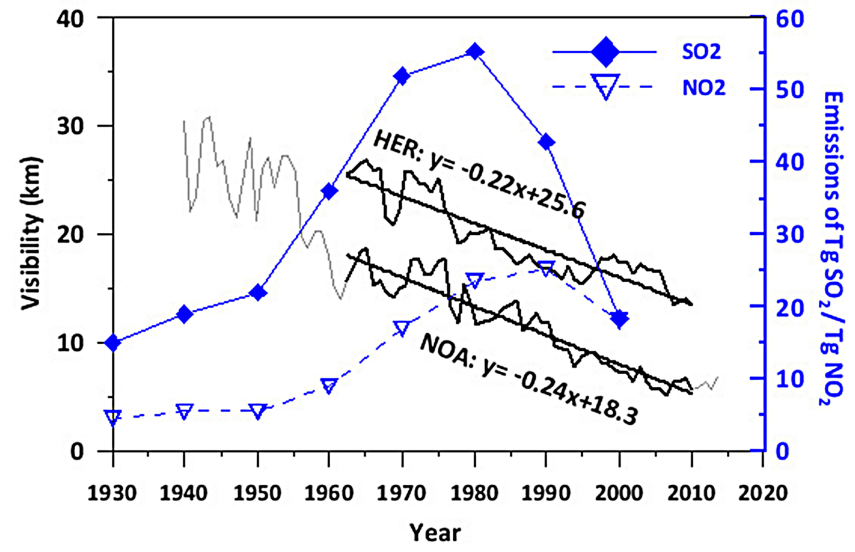

Figure 11. Interdecadal variability of the annual average visibility at NOA (urban) and HER (background) stations. Bold black lines represent the common period of observations (1956-2009) at the two stations, along with linear trends and slopes. The solid blue line illustrates historical development of European emissions of $\mathrm{SO}_{2}$, as included in Vestreng et al. (2007), and the blue dashed line illustrates historical European emissions of $\mathrm{NO}_{x}$, as included in Vestreng et al. (2009).

while air pollution is also blocked within the boundary layer by the mountain chain.

\subsection{Air pollution and urbanization relations to visibility}

In this section we attempt to interpret the observed interdecadal variability and trends of visibility in Athens in terms of air pollution. As already shown in Fig. 4, the pre-1950 period is characterized by considerably higher visibility levels in Athens. From then on, visibility experienced a rapid decrease, followed by a smoother but continuous decreasing trend until the early 2000s. The period after 1950 signifies the post-World War II epoch but also coincides with the end of a civil war in Greece (1946-1949), which was followed by an important urbanization wave in Athens (Maloutas, 2003). This is in line with the rapid growth of Athens' population, as illustrated in Fig. 4. The greatest rate of population increase is observed between 1950 and 1960, when population in Athens almost doubled. The population growth was associated with a significant increase of construction in the city. However, apart from the intense urbanization in Athens, this period is also characterized by the most prominent increase of anthropogenic emissions on a global and European scale (e.g., Mylona, 1996; van Aardenne et al., 2001; Vestreng et al., 2007, 2009).

Are the changes in visibility in Athens due to local factors or can they be considered representative of a more extensive area? To answer this question, the Athens visibility record was compared with visibility at a non-urban reference station. From the available stations in Greece with long-term visibility observations, we chose the station at HER on the island of Crete (Fig. 1). Actually, both sites, NOA and HER, are exposed, most of the year, to air masses of similar origin (from north and northeasterly directions) traveling over the Aegean Sea, in contrast to other sites of the country that are strongly affected by the mountainous volumes of the Greek mainland. Visibility observations at HER are available since the mid-1950s. Figure 11 presents the long-term variation of the annual averages of visibility at HER along with the annual visibility at NOA. Linear trends of the time series for their common period (1956-2009) are also shown in the figure. The time series were found significantly correlated (correlation coefficient $>0.88, p<0.05$ ).

According to Fig. 11, visibility levels at urban NOA are constantly lower by a few kilometers $(\sim 7 \mathrm{~km})$ compared to the background station, HER. It is remarkable that, during the first 2 decades of parallel observations, both curves show significant covariance, easily realized from the peaks in 1959 , 1966 and 1970 and the minima in 1963 and 1973, suggesting the impact of large scale phenomena (for instance, volcanic eruptions in 1963) on the modulation of visibility levels. A prominent feature in Fig. 11 is that the background visibility at the reference site has also been on a downward route since the mid-1950s, in accordance with the observed decreasing trend of visibility in Athens. As already stated, the beginning of the 1950s corresponds to a period with significant increase of emissions in Europe. European emissions of $\mathrm{SO}_{2}$ in particular increased almost at a constant rate during the first half of the 20th century, while they experienced a quite abrupt increase in the 1950s (Mylona, 1996; van Aardenne et al., 2001; Vestreng et al., 2007). Figure 11 includes the historical development of $\mathrm{SO}_{2}$ and $\mathrm{NO}_{2}$ emissions in Europe since 1930, as reported by Vestreng et al. (2007) and Vestreng et al. (2009), respectively. A slow and constant increase in $\mathrm{SO}_{2}$ emissions is observed until the 1950s (although the emissions decreased during World War II), related to the increased energy demand and use of solid fuels. A sharp increase in sulfur emissions takes place afterwards, as a result of ongoing energy demand and availability of liquid fuels (Vestreng et al., 2007), and in the late 1970s sulfur emissions were higher by a factor of nearly 2.5 compared to the 1950 s levels, exceeding $50 \mathrm{Tg} \mathrm{SO}$. After a short stabilization in the 1980 s, a sudden reduction in sulfur emissions takes place (most prominent after 1990), which in the 2000s almost corresponds to the levels of 1930. Historical development of $\mathrm{NO}_{x}$ emissions in Europe exhibits a similar pattern (Fig. 11), with pronounced increase in emissions from 1950 to 1980 , a tendency to stabilization between 1980 and 1990 and a decline thereafter. The plot of $\mathrm{NO}_{x}$ emissions in Fig. 11 refers to all emission sectors, as included in Vestreng et al. (2009).

Segregation of emission trends by air mass origin would further enlighten their possible effect on visibility variation in Athens. As stated in Sect. 2.2, air masses from the NNE sectors dominate in Athens, contributing by more than $60 \%$ on an annual basis. Following segregation of European $\mathrm{SO}_{2}$ emissions by country as reported by Mylona (1996), 
it is found that emissions by countries of the N-NE sector (as defined in Fig. 2a) have the largest contribution in total European emissions. Sulfur dioxide emissions increased by a factor of approximately 2.5 between 1950 and 1980 in these regions, which is analogous to the increase of total European emissions over the same period. According to Mylona (1996), the contribution of emissions from the former USSR (but also Turkey) is very important after 1940. The EMEP part of USSR in particular contributed to almost onequarter of the total emissions in the 1970s. Sulfur emissions declined after the 1990s in both eastern and western Europe, but with higher rates (by a factor of 1.5) in eastern Europe as a result of the economic recession after 1990 in these countries (Vestreng et al., 2007; Stjern et al., 2011).

In regard to other types of emissions such as organic carbon (OC) or black carbon (BC), historical data reported by Bond et al. (2007) show an increase of the order of $50 \%$ on a global scale between 1930 and 2000. However, segregation by region indicates that European emissions of OC and BC revealed a slight increase between 1950 and 1970 and decrease thereafter. Decreasing trends are also observed in the former USSR after 1970 (Bond et al., 2007).

A very interesting finding in Fig. 11 is the similar slopes in the negative linear trends of the annual visibility at the background and urban stations over their common period of observations ( -2.2 and $-2.4 \mathrm{~km} \mathrm{decade}^{-1}$, respectively). This feature implies that the interdecadal variability of visibility in the Eastern Mediterranean is significantly modulated by large scale processes that control visibility, such as longrange pollution transport. Many studies have identified the Eastern Mediterranean as a crossroad of aerosols of different origins, sizes and chemical composition (Lelieveld et al., 2002; Hatzianastassiou et al., 2009; Kanakidou et al., 2011; Gerasopoulos et al., 2011), which inevitably affect optical properties of the atmosphere.

After the early 1990s, the two time series diverge. Background visibility at HER partly recovers, while visibility at NOA keeps declining at the same pace until 2003 (Fig. 11). Recovering visibility is also found at other Greek areas around the 1990s (Lianou et al., unpublished data), which is in line with visibility improvement in other European areas related to emissions reduction (Vautard et al., 2009; Wang et al., 2009). This last feature suggests that, during this period, local emissions might have a dominant role in the determination of visibility in Athens.

A slight recovery of visibility is observed during the decade 2004-2013 (Figs. 4, 11). This improvement could be attributed to a number of reasons. The years after 2004 correspond to the post-Olympic Games period in Athens. A number of important transport projects were completed prior to the Olympic Games in Athens in 2004. Such projects are for instance the construction of the Attica Ring Road (one of the largest in Europe), the construction of Tramway and the extension of Athens Metro. These projects have contributed to the reduction in the number of vehicles in the city, re- sulting in less traffic problems and lower air pollution levels. Another possible contributing factor concerns the impact of the Greek economic recession (2008-2013) on air quality in Greece, and Athens in particular. Recent studies provide some evidence on this. For instance, Vrekoussis et al. (2013) found strong correlation between different economic metrics and air pollutants after 2007, suggesting that the economic recession has resulted in proportionally reduced levels of air pollutants in the two biggest cities in Greece. This is further supported by other recent research studies that report a significant reduction in energy consumption after 2008, related to the rapid economic degradation (Santamouris et al., 2013).

\subsection{Visibility in Athens and AOD}

The relationship of visibility with AOD over Athens was also explored, using two different satellite-based datasets (AVHRR and MODIS) from 1981-2009 and 2000-2014, respectively (see Sect. 2.5). For the AVHRR AOD at $630 \mathrm{~nm}$, Fig. 12a shows a $1.7 \%$ per year decrease from 1981 to 1997 and a $2.4 \%$ decrease from 1999 to 2009 (1998 data were not available). It is interesting to note the AOD maxima in 1991 and 1992 that are linked with the Pinatubo eruption period. The AOD time series for the MODIS instrument at $550 \mathrm{~nm}$ showed a significant and similar to AVHRR (2.4\% per year) decrease from 2000 to 2009 and a further decrease of $7.4 \%$ per year for the period 2010-2014 (Fig. 12b).

To investigate the relationship between visibility and AOD changes, the two parameters are plotted together after data binning. Visibility and AOD measurements have been used as follows: visibility at 12:00 UT was used according to the indices defined in Table 2 and plotted against average AOD from synchronous satellite overpasses of AVHRR and MODIS separately. The mean AOD and its standard deviation are presented in Fig. 13. Average AOD from AVHRR and MODIS are not directly comparable, as they represent different time periods and different wavelengths. The AOD values are related to the visibility data, using the middle point of each visibility bin (range) as the distance in kilometers. Only summertime (June-August) MODIS and AVHRR AODs have been used, to keep visibility values unaffected by other atmospheric parameters like low clouds, rain or relative humidity. It is observed that for average AOD values over Athens ( 0.25 using the mean June-August AOD at $550 \mathrm{~nm}$ from our MODIS AOD dataset or 0.23 at $500 \mathrm{~nm}$ as reported by Gerasopoulos et al., 2011), visibility varies within the range of 4 to $10 \mathrm{~km}$. Under cleaner conditions (WNW-N, 0.12-0.17 at $500 \mathrm{~nm}$; Gerasopoulos et al., 2011), visibility can reach as high as $20 \mathrm{~km}$, while very low visibility $(<0.5 \mathrm{~km})$ is generally associated with the highest aerosol load, with AOD > 0.3 (e.g., in the case of dust events, longrange transport of urban/industrial pollutants and stagnant conditions). Including both satellite datasets in the same figure provides information only on the summertime AOD vs. visibility relationship. 


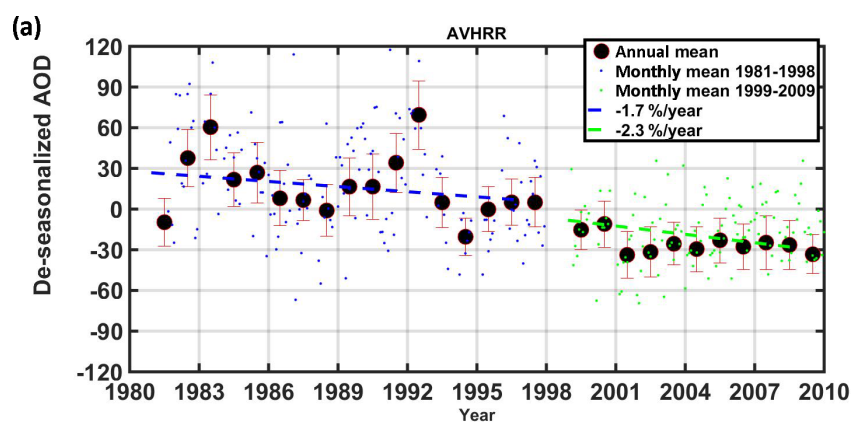

(b)

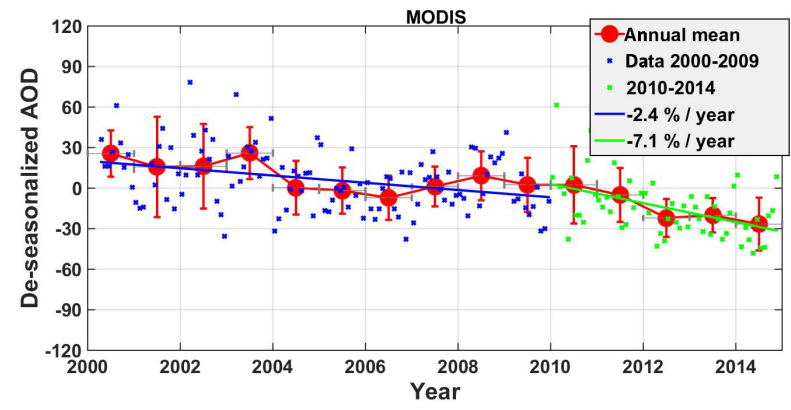

Figure 12. (a) Variability of de-seasonalized monthly AVHRRbased $\mathrm{AOD}_{630 \mathrm{~nm}}$ from 1981 to 2009 (black), along with linear trends for the periods 1981-1997 (blue) and 1998-2009 (green). Vertical bars describe the standard deviation of the annual value based on the monthly ones (upper graph). (b) Variability of MODISbased de-seasonalized monthly AOD $_{550 \mathrm{~nm}}$ from 2000 to 2014 (red), along with linear trends for the periods 2000-2009 (blue) and 2010-2014 (green). Vertical bars describe the standard deviation of the annual value based on the monthly ones and grey horizontal bars the respective year (lower graph).

Illustrating the relationship between AOD, which consists of a vertically integrated parameter, and visibility, a horizontally integrated parameter, requires various assumptions. Using satellite-based AOD and visibility observations for GAA, when assuming a vertically constant extinction coefficient and a mixing layer that contains all aerosol load we end up describing the theoretical relationship (Koschmieder, 1924): $\mathrm{Vis}=k / \mathrm{AOD}$, where $k$ is a function of the mixing layer height.

\subsection{Visibility in relation to $\mathrm{PM}_{10}$}

An additional analysis was conducted to verify the relationship between visibility and particulate pollution from surface measurements, using a short dataset of $\mathrm{PM}_{10}$ in Athens as described in Sect. 2.5. Figure 14 presents visibility variation as a function of $\mathrm{PM}_{10}$ levels, measured at Aristotelous (urban) and Maroussi (suburban) stations. Four different classes of $\mathrm{PM}_{10}$ levels were used, as shown in Fig. 14. The frequency of occurrence of each class is also shown in the figure. Despite the different locations and characteristics of the two stations, the observed frequencies are very similar in all classes of $\mathrm{PM}_{10}$ levels, with higher frequency corresponding

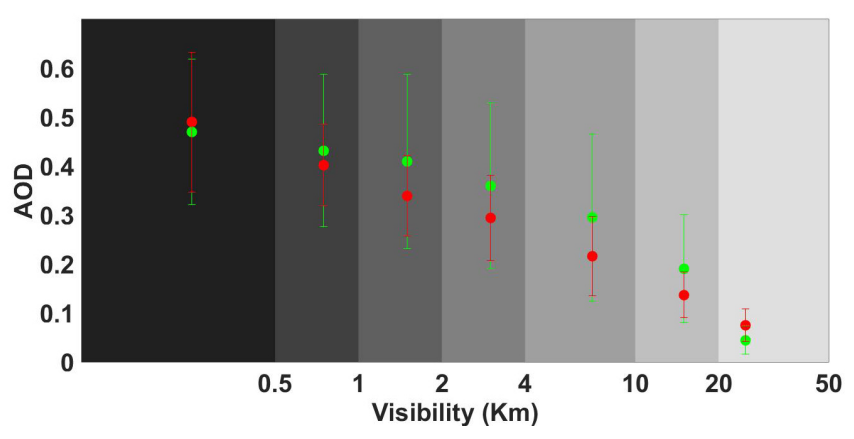

Figure 13. MODIS at $550 \mathrm{~nm}$ (green) (2000-2014) and AVHRR at $630 \mathrm{~nm}$ (red) (1981-2009), AOD (June-August) mean values and standard deviations for each visibility index. Shaded areas represent visibility ranges $(\mathrm{km})$ for each visibility class (Table 2$)$. AOD averages have been represented here in the average distance from each class.

to the class of $30-60 \mu \mathrm{g} \mathrm{m}^{-3}$ at both stations. The frequency of $\mathrm{PM}_{10}>90 \mu \mathrm{g} \mathrm{m}^{-3}$ at Aristotelous is double compared to the respective frequency at Maroussi. Independent of the location, the same strong relationship is observed between visibility reported at NOA and $\mathrm{PM}_{10}$ levels at both stations, revealing a prominent decrease in visibility with increasing $\mathrm{PM}_{10}$ levels, in agreement with our conclusions. Average visibility at NOA ranges between 8 and $9 \mathrm{~km}$ under low $\mathrm{PM}_{10}$ levels $\left(<30 \mu \mathrm{g} \mathrm{m}^{-3}\right)$ but is reduced to less than $3 \mathrm{~km}$ under severe episodes of particulate pollution $\left(\mathrm{PM}_{10}>90 \mu \mathrm{g} \mathrm{m}^{-3}\right)$. The correlation coefficient between daily $\mathrm{PM}_{10}$ levels and daily visibility at NOA was found equal to $-0.38(p<0.05)$ and $-0.36(p<0.05)$ for Aristotelous and Maroussi sites, respectively.

Finally, the variation of the annual averages of $\mathrm{PM}_{10}$ values in Athens (Maroussi and Aristotelous stations) from 2004 to 2014 and at the reference site of Finokalia (available over the 10-year period 2005-2014) is displayed in Fig. 15. A decreasing tendency in $\mathrm{PM}_{10}$ levels is observed at all sites, indicating changes on both local and regional scales. Decreasing trends are more pronounced in Athens and particularly at Maroussi station $\left(-2.4 \mu \mathrm{g} \mathrm{m}^{-3}\right.$ year $\left.^{-1}\right)$. The decreasing trend in $\mathrm{PM}_{10}$ levels is consistent with the slight improvement of visibility in Athens over the same period.

\section{Discussion and conclusions}

The present work analyses, for the first time, the long historical record of visibility at NOA (Athens) from 1931 to 2013 and interprets its temporal variability and trends in terms of relevant changes in atmospheric properties (related to local or regional processes) and/or meteorological conditions. Since this is the longest record of visibility observations in Greece and one of the oldest in the broader area of the Eastern Mediterranean, the study provides unique information on the atmospheric properties of the area in the past, when air 

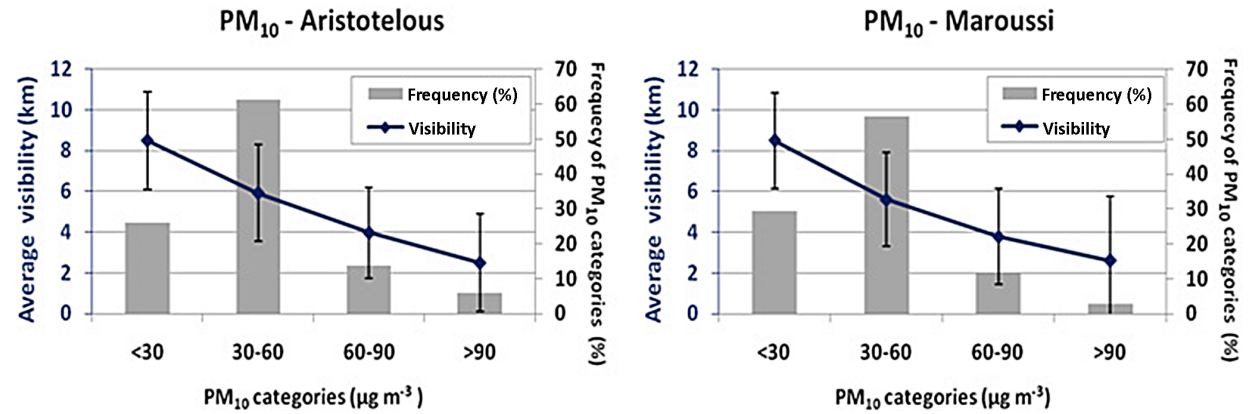

Figure 14. Visibility as a function of different classes of $\mathrm{PM}_{10}$ levels at an urban (Aristotelous, left graph) and a suburban (Maroussi, right graph) station in Athens. Measurements refer to the period 2008-2012. Geometric average and standard deviation are applied on visibility observations. Relative frequencies of different $\mathrm{PM}_{10}$ classes are also shown (grey bars).

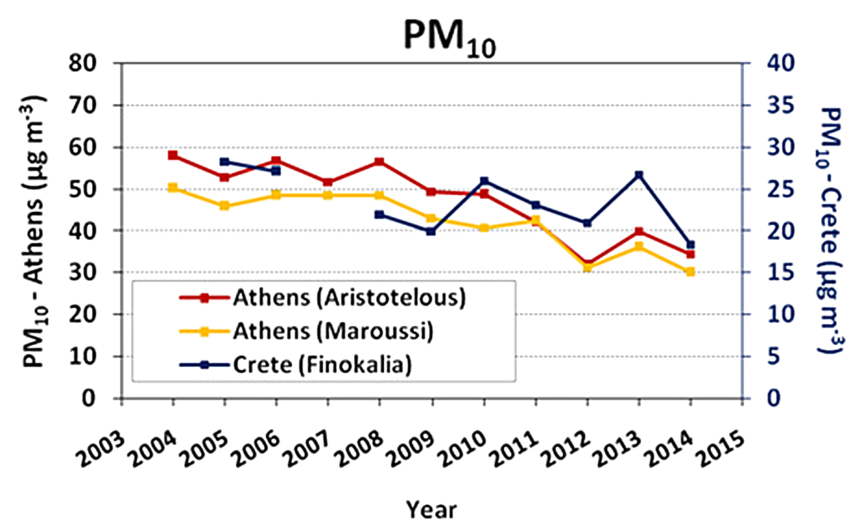

Figure 15. Variation of the annual $\mathrm{PM}_{10}$ levels at the reference station of Finokalia (2005-2014) and at the stations of Maroussi and Aristotelous in Athens (2004-2014).

pollution records are missing. The study period was divided into subperiods corresponding to different trends in the time series of visibility, each subperiod being affected by different factors.

The impact of meteorological conditions on visibility was investigated in different ways. Visibility in Athens was found to follow a seasonal cycle, with higher visibility corresponding to the warm and dry months of the year. Seasonality is more distinct in the first subperiod of the time series (19311948), while after the 1950s the seasonal cycle attenuates. Visibility was found to be negatively correlated with RH, the correlation being stronger in the early part of the time series and attenuating over the years. In contrast, a positive correlation between visibility and wind speed was found, statistically significant during the late part of the time series, suggesting the increasing role of winds on the cleanup of the atmosphere from air pollutants. Visibility was also found to be sensitive to wind direction, reflecting the influence of air mass origin. Lower visibility levels are constantly observed under southerly winds, corresponding to sea breeze circulation as well as to African dust outbreaks.
The study demonstrated that visibility in Athens has undergone a prominent impairment since the early 1930s. The overall trend of the annual visibility averages was found equal to $-2.8 \mathrm{~km} \mathrm{decade}^{-1}$. The impressively higher levels of visibility in Athens before the 1950s (also characterized by strong seasonality) reflect the transparency of the atmosphere at that period, coherent with the poorer aerosol load from anthropogenic emissions (urban and/or regional). The dramatic decrease of the visual air quality in the 1950s coincides with a number of events (end of wars, rapid urbanization and rapid increase of anthropogenic emissions on local and regional scale) and points to the prominent role of aerosol load in the atmosphere of Athens. Air pollution has gradually incurred a severe visual pollution in the city, with visibility lower than $4 \mathrm{~km}$ observed during more than half of the year in the decade 2004-2013.

The comparison of the annual averages of visibility in Athens and at a non-urban reference site (HER) in Crete, revealed similar and statistically significant negative trends at both sites, suggesting the major contribution of long- and regional-range transport of natural and anthropogenic pollution in the GAA. An improvement of visibility at HER around the 1990s was not associated with synchronous improvement of visibility in Athens, where visibility deterioration continued until the early 2000s. Although negative trends of main gaseous air pollutants are reported in Athens at that period (Kalabokas et al., 1999a), the direct effect of such pollutants on light extinction is negligible compared to suspended particles and particularly to fine particles $(<1 \mu \mathrm{m})$.

The relationship between AOD and visibility in Athens was also examined in the study, using MODIS and AVHRR satellite data (Figs. 12,13), and confirmed their negative correlation. Also, a strong anticorrelation was found between visibility and $\mathrm{PM}_{10}$ levels in Athens, measured at two different stations (urban and suburban) over the period 2008-2012 (Fig. 14).

The analysis showed a recent stabilization (or even slight improvement) of visibility in Athens, consistent with the ob- 
served decreasing trends of $\mathrm{PM}_{10}$ in the city from 2004 to 2014 (Fig. 15). This could possibly be related to the reduction of local anthropogenic emissions as a result of not only important new transport infrastructures but also the economic recession in Greece. Although this last argument is already supported by some recent research studies, the impact of economic recession on local emissions seems to be more complicated and drawing conclusions remains tentative. Besides, in the same period, regional atmospheric pollution presents a decreasing tendency (Fig. 15), which is also consistent with the recent recovery of visibility in Athens.

The 82-year-long time series of visibility in Athens unfolded for the first time information on the atmospheric conditions over the area, for periods when atmospheric pollution measurements are missing. Although the analysis is subject to several limitations and assumptions, mainly associated with the methods of visibility observations, the results are robust and statistically significant, showing an outstanding degradation of the visual air quality in the city from the 1930 s to the 2000s.

\section{Data availability}

All data are available upon request to the authors.

\section{The Supplement related to this article is available online at doi:10.5194/acp-16-11219-2016-supplement.}

Acknowledgements. The study is a contribution to the ChArMEX (The Chemistry-Aerosol Mediterranean Experiment) work package on variability and trends. The study was supported by the Excellence Research Program GSRT- Siemens (2015-2017) ARISTOTELIS "Environment, Space and Geodynamics/Seismology 2015-2017" in the framework of the Hellenic Republic-Siemens Settlement Agreement. The authors are grateful to the Editor François Dulac and the two anonymous reviewers for their very useful comments and suggestions on this study. The authors would also like to thank the Hellenic National Meteorological Service (HNMS) for the provision of visibility data at Heraklion (Crete) and the Air Quality Department of the Ministry of Environment and Energy of Greece for the provision of air pollution data. The contributions of F. Pierros (NOA) and D. Koutentaki (NOA) in the digitization of visibility data of NOA and of G. Kouvarakis (University of Crete) in the analysis of air trajectories are also acknowledged. Finally, the important contribution of all operators in the acquisition and maintenance of uninterrupted, continuous and reliable historical climatic records of NOA is acknowledged.

Edited by: F. Dulac

Reviewed by: two anonymous referees

\section{References}

Appel, B. R., Tokiwa, Y., Hsu, J., Kothny, E., and Hahn, E.: Visibility as related to atmospheric aerosol constituents, Atmos. Environ., 19, 1525-1534, doi:10.1016/0004-6981(85)90290-2, 1985.

Bäumer, D., Vogel, B., Versick, S., Rinke, R., Möhler, O., and Schnaiter, M.: Relationship of visibility, aerosol optical thickness and aerosol size distribution in an ageing air mass over South-West Germany, Atmos. Environ., 42, 989-998, doi:10.1016/j.atmosenv.2007.10.017, 2008.

Bond, T. C., Bhardwaj, E., Dong, R., Jogani, R., Jung, S., Roden, C., Streets, D. G., and Trautmann, N. M.: Historical emissions of black and organic carbon aerosol from energy-related combustion, 1850-2000, Global Biogeochem. Cy., 21, GB2018, doi:10.1029/2006GB002840, 2007.

Carapiperis, L. N. and Karapiperis, P. P.: On the ocean colour of the sky in Athens, Academy of Athens, 27, 211-215, 1952.

Cermak, J., Wild, M., Knutti, R., Mishchenko, M. I., and Heidinger, A. K.: Consistency of global satellite-derived aerosol and cloud data sets with recent brightening observations, Geophys. Res. Lett., 37, L21704, doi:10.1029/2010GL044632, 2010.

Chaloulakou, A., Kassomenos, P., Spyrellis, N., Demokritou, P., and Koutrakis, P.: Measurements of $\mathrm{PM}_{10}$ and $\mathrm{PM}_{2.5}$ particle concentrations in Athens, Greece, Atmos. Environ., 37, 649-660, doi:10.1016/S1352-2310(02)00898-1, 2003.

Chan, P. K., Zhao, X. P., and Heidinger, A. K.: Long-Term Aerosol Climate Data Record Derived from Operational AVHRR Satellite Observations, Dataset Papers in Geosciences, 2013, 140791, doi:10.7167/2013/140791, 2013.

Chan, Y. C., Simpson, R. W., Mctainsh, G. H., Vowles, P. D., Cohen, D. D., and Bailey, G. M.: Source apportionment of visibility degradation problems in Brisbane (Australia) using the multiple linear regression techniques, Atmos. Environ., 33, 3237-3250, doi:10.1016/S1352-2310(99)00091-6, 1999.

Chang, D., Song, Y., and Liu, B.: Visibility trends in six megacities in China 1973-2007, Atmos. Res., 94, 161-167, doi:10.1016/j.atmosres.2009.05.006, 2009.

Che, H. Z., Zhang, X. Y., Li, Y., Zou, Z. J., and Qu, J. J.: Horizontal visibility trends in China 1981-2005, Geophys. Res. Lett., 34, L24706, doi:10.1029/2007GL031450, 2007.

Colbeck, I., Chung, M. C., and Eleftheriadis, K.: Formation and transport of atmospheric aerosol over Athens, Greece, Water Air Soil Pollut., 2, 223-235, doi:10.1023/A:1021335401558, 2002.

Davis, R. E.: A synoptic climatological analysis of winter visibility trends in the mideastern United States, Atmos. Environ., 25b, 165-175, doi:10.1016/0957-1272(91)90052-G, 1991.

Dayan, U. and Levy, I.: The Influence of Meteorological Conditions and Atmospheric Circulation Types on $\mathrm{PM}_{10}$ and Visibility in Tel Aviv, J. Appl. Meteorol., 44, 606-619, doi:10.1175/JAM2232.1, 2005.

Deng, J. J., Wang, T. J., Jiang, Z. Q., Xie, M., Zhang, R. J., Huang, X. X., and Zhu, J. L.: Characterization of visibility and its affecting factors over Nanjing, China, Atmos. Res., 101, 681-691, doi:10.1016/j.atmosres.2011.04.016, 2011.

Doyle, M. and Dorling, S.: Visibility trends in the UK 19501997, Atmos. Environ., 36, 3161-3172, doi:10.1016/S13522310(02)00248-0, 2002.

Draxler, R., Stunder, B., Rolph, G., Stein, A., and Taylor, A.: Hybrid Single-Particle Lagrangian Integrated Trajectories (HYSPLIT): Version 4.9 - User's Guide and Model Descrip- 
tion, available at: http://www.arl.noaa.gov/documents/reports/ hysplit_user_guide.pdf (last access: 3 September 2016), 2009.

Eidels-Dubovoi, S.: Aerosol impacts on visible light extinction in the atmosphere of Mexico City, Sci. Total Environ., 287, 213220, doi:10.1016/S0048-9697(01)00983-4, 2002.

Elias, T., Haeffelin, M., Drobinski, P., Gomes, L., Rangognio, J., Bergot, T., Chazette, P., Raut, J. C., and Colomb, M.: Particulate contribution to extinction of visible radiation: pollution, haze, and fog, Atmos. Res., 92, 443-454, doi:10.1016/j.atmosres.2009.01.006, 2009.

Eltbaakh, Y. A., Ruslan, M. H., Alghoul, M. A., Othman, M. Y., and Sopian, K.: Issues concerning atmospheric turbidity indices, Renew. Sustain. Energ. Rev., 16, 6285-6294, doi:10.1016/j.rser.2012.05.034, 2012.

Folini, D. and Wild, M.: Aerosol emissions and dimming/brightening in Europe: Sensitivity studies with ECHAM5HAM, J. Geophys. Res., 116, D21, doi:10.1029/2011JD016227, 2011.

Founda, D.: Evolution of the air temperature in Athens and evidence of climatic change: A review, Advances in Building Energy Research, 5, 7-41, doi:10.1080/17512549.2011.582338, 2011.

Founda, D., Pierros, F., Petrakis, M., and Zerefos, C.: Interdecadal variations and trends of the Urban Heat Island in Athens (Greece) and its response to heat waves, Atmos. Res., 161, 1-13, doi:10.1016/j.atmosres.2015.03.016, 2015.

Gerasopoulos, E., Kouvarakis, G., Vrekoussis, M., Kanakidou, M., and Mihalopoulos, N.: Ozone variability in the marine boundary layer of the Eastern Mediterranean based on 7-year observations, J. Geophys. Res., 110, D15309, doi:10.1029/2005JD005991, 2005.

Gerasopoulos, E., Amiridis, V., Kazadzis, S., Kokkalis, P., Eleftheratos, K., Andreae, M. O., Andreae, T. W., El-Askary, H., and Zerefos, C. S.: Three-year ground based measurements of aerosol optical depth over the Eastern Mediterranean: the urban environment of Athens, Atmos. Chem. Phys., 11, 2145-2159, doi:10.5194/acp-11-2145-2011, 2011.

Ghim, Y. S., Moon, K., Lee, S., and Kim, Y. P.: Visibility trends in Korea during the past two decades, J. Air Waste Manage., 55, 73-82, doi:10.1080/10473289.2005.10464599, 2005.

Gkikas, A., Basart, S., Hatzianastassiou, N., Marinou, E., Amiridis, V., Kazadzis, S., Pey, J., Querol, X., Jorba, O., Gassó, S., and Baldasano, J. M.: Mediterranean intense desert dust outbreaks and their vertical structure based on remote sensing data, Atmos. Chem. Phys., 16, 8609-8642, doi:10.5194/acp-16-86092016, 2016.

Grivas, G., Chaloulakou, A., Samara, C., and Spyrellis, N.: Spatial and temporal variation of $\mathrm{PM}_{10}$ mass concentrations within the Greater Area of Athens, Greece, Water Air Soil Pollut., 158, 357-371, doi:10.1023/B:WATE.0000044859.84066.09, 2004.

Hamonou, E., Chazette, P., Balis, D., Dulac, F., Schneider, X., Galani, E., Ancellet, G., and Papayannis, A.: Characterization of the vertical structure of Saharan dust export to the Mediterranean basin, J. Geophys. Res., 104, 22257-22270, doi:10.1029/1999JD900257, 1999.

Hand, J. L., Kreidenweis, S. M., Sherman, D. E., Collett Jr., J. L., Hering, S. V., Day, D. E., and Malm, W. C.: Aerosol size distributions and visibility estimates during the Big Bend Regional Aerosol and Visibility Observational (BRAVO) study, Atmos.
Environ., 36, 5043-5055, doi:10.1016/S1352-2310(02)00568-X, 2002.

Hatzianastassiou, N., Gkikas, A., Mihalopoulos, N., Torres, O., and Katsoulis, B. D.: Natural versus anthropogenic aerosols in the eastern Mediterranean basin derived from multiyear TOMS and MODIS satellite data, J. Geophys. Res., 114, D24202, doi:10.1029/2009JD011982, 2009.

Hoek, G., Forsberg, B., Borowska, M., Hlawiczka, S., Vaskovi, E., Welinder, H., Branis, M., Benes, I., Kotesovec, F., Hagen, L. O., Cyrys , J., Jantunen, M., Roemer, W., and Brunekreef, B.: Wintertime $\mathrm{PM}_{10}$ and black smoke concentrations across Europe: results from the Peace study, Atmos. Environ., 31, 3609-3622, doi:10.1016/S1352-2310(97)00158-1, 1997.

Ichoku, C., Chu, D.A., Mattoo, S., Kaufman, Y. J., Remer, L. A., Tanré, D., Slutsker, I., and Holben, B. N.: A spatio-temporal approach for global validation and analysis of MODIS aerosol products, Geophys. Res. Lett., 29, 1-4, doi:10.1029/2001GL013206, 2002.

Kalabokas, P. D., Viras, L. G., and Repapis, C. C.: Analysis of 11-year record (1987-1997) of air pollution measurements in Athens, Greece, Part I: primary air pollutants, Global Nest, 1, 157-167, 1999a.

Kalabokas, P. D., Viras, L. G., Repapis, C. C., and Bartzis, J. G.: Analysis of 11-year record (1987-1997) of air pollution measurements in Athens, Greece, Part II: photochemical air pollutants, Global Nest, 1, 169-176, 1999 b.

Kanakidou, M., Mihalopoulos, N., Kindap, T., Im, U., Vrekoussis, M., Gerasopoulos, E., Dermitzaki, E., Unal, A., Koçak , M., Markakis, K., Melas, D., Kouvarakis, G., Youssef, A. F., Richter, A., Hatzianastassiou, N., Hilboll, A., Ebojie, F., Wittrock, F., von Savigny, C., Burrows, J. P., Ladstaetter-Weissenmayer, A., and Moubasher, H.: Megacities as hot spots of air pollution in the East Mediterranean, Atmos. Environ., 45, 1223-1235, doi:10.1016/j.atmosenv.2010.11.048, 2011.

Kanellopoulou, E.: Study of the visibility of Athens, PhD Thesis, National and Kapodistrian University of Athens, 1979 (in Greek).

Kim, K. W.: Physico-chemical characteristics of visibility impairment by airborne pollen in an urban area, Atmos. Environ., 41, 3565-3576, doi:10.1016/j.atmosenv.2006.12.054, 2007.

Kim, K. W.: Optical Properties of Size-Resolved Aerosol Chemistry and Visibility Variation Observed in the Urban Site of Seoul, Korea, Aerosol Air Qual. Res., 15, 271-283, doi:10.4209/aaqr.2013.11.0347, 2015.

Koschmieder, H.: Theorie der horizontalen sichtweite, Beitr. Phys. Frei. Atmos., 12, 171-181, 1924.

Kouvarakis, G., Tsigaridis, K., Kanakidou, M., and Mihalopoulos, N.: Temporal variations of surface regional background ozone over Crete Island in southeast Mediterranean, J. Geophys. Res., 105, 4399-4407, doi:10.1029/1999JD900984, 2000.

Larson, S. M. and Cass, G. R.: Characteristics of summer midday low-visibility events in the Los Angeles area, Environ. Sci. Technol., 23, 281-289, doi:10.1021/es00180a003, 1989.

Lee, D. O.: Regional variations in long-term visibility trends in the UK (1962-1990), Geography, 79, 108-121, 1994.

Lelieveld, J., Berresheim, H., Borrmann, S., Crutzen, P. J., Dentener, F. J., Fischer, H., Feichter, J., Flatau, P. J., Heland, J., Holzinger, R., Korrmann, R., Lawrence, M. G., Levin, Z., Markowicz, K. M., Mihalopoulos, N., Minikin, A., Ramanathan, 
V., de Reus, M., Roelofs, G. J., Scheeren, H. A., Sciare, J., Schlager, H., Schultz, M., Siegmund, P., Steil, B., Stephanou, E. G., Stier, P., Traub, M., Warneke, C., Williams, J., and Ziereis, H.: Global Air Pollution Crossroads over the Mediterranean, Science, 298, 794-799, doi:10.1126/science.1075457, 2002.

Léon, J.-F., Chazette, P., and Dulac, F.: Retrieval and monitoring of aerosol optical thickness over an urban area by spaceborne and ground-based remote sensing, Appl. Optics, 38, 6918-6926, doi:10.1364/AO.38.006918, 1999.

Malm, W. C.: Introduction to Visibility, Air Resources Division, National Park Service, Cooperative Institute for Research in the Atmosphere (CIRA), NPS Visibility Program, Colorado State University, Fort Collins, CO, May, 1999.

Maloutas, T.: The self promoting housing solution in post war Athens, Discussion Paper Series 9(6) 95-110, available at: http://www.prd.uth.gr/research/DP/2003/uth-prd-dp-2003-6_ en.pdf (last access: 3 September 2016), 2003.

Mavroidis, I. and Ilia, M.: Trends of $\mathrm{NO}_{x}, \mathrm{NO}_{2}$ and $\mathrm{O}_{3}$ concentrations, at three different types of air quality monitoring stations in Athens, Greece, Atmos. Environ., 63, 135-147, doi:10.1016/j.atmosenv.2012.09.030, 2012.

Mishchenko, M. I., Geogdzhayev, I. V., Rossow, W. B., Cairns, B., Carlson, B. E., Lacis, A. A., Liu, L., and Travis, L. D.: Long-term satellite record reveals likely recent aerosol trend, Science, 315, p. 1543, doi:10.1126/science.1136709, 2007.

Mylona, S.: Sulfur dioxide emissions in Europe 1880-1991 and their effect on sulphur concentrations and depositions, Tellus, 48, 662-689, doi:10.1034/j.1600-0889.1996.t01-2-00005.x, 1996.

Nabat, P., Somot, S., Mallet, M., Sanchez-Lorenzo, A., and Wild, M.: Contribution of anthropogenic sulfate aerosols to the changing Euro-Mediterranean climate since 1980, Geophys. Res. Lett., 41, 5605-5611, doi:10.1002/2014GL060798, 2014.

Paraskevopoulou, D., Liakakou, E., Gerasopoulos, E., Theodosi, C., and Mihalopoulos, N.: Long-term characterization of organic and elemental carbon in the $\mathrm{PM}_{2.5}$ fraction: the case of Athens, Greece, Atmos. Chem. Phys., 14, 13313-13325, doi:10.5194/acp-14-13313-2014, 2014.

Paraskevopoulou, D., Liakakou, E., Gerasopoulos, E., and Mihalopoulos, N.: Sources of atmospheric aerosols from longterm measurements (5 years) of chemical composition in Athens, Greece, Sci. Total Environ., 527-528, 165-178, doi:10.1016/j.scitotenv.2015.04.022, 2015.

Remoudaki, E., Gergametti, G., and Losno, R.: On the dynamic of the atmospheric input of copper and manganese into the western Mediterranean Sea, Atmos. Environ., 25A, 733-744, doi:10.1016/0960-1686(91)90072-F, 1991a.

Remoudaki, E., Gergametti, G., and Buat-Ménard, P.: Temporal variability of atmospheric lead concentrations and fluxes over the northwestern Mediterranean Sea, J. Geophys. Res., 96, 10431055, doi:10.1029/90JD00111, 1991b.

Santamouris, M., Paravantis, J. A., Founda, D., Kolokotsa, D., Michalakakou, P., Papadopoulos, A. M., Kontoulis, N., Tzavali, A., Stigka, E. K., Ioannidis, Z., Mehilli, A., Matthiessen, A., and Servou, E.: Financial Crisis and Energy Consumption: A household Survey in Greece, Energy Build., 65, 477-487, doi:10.1016/j.enbuild.2013.06.024, 2013.

Singh, A. and Dey, S.: Influence of aerosol composition on visibility in megacity Delhi, Atmos. Environ., 62, 367-373, doi:10.1016/j.atmosenv.2012.08.048, 2012.
Sloane, C. S.: Visibility trends - II. Mideastern United States 1948-1978, Atmos. Environ., 16, 2309-2321, doi:10.1016/00046981(82)90117-2, 1982.

Smirnov, A., Holben, B. N., Sakerin, S. M., Kabanov, D. M., Slutsker, I., Chin, M., Diehl, T. L., Remer, L. A., Kahn, R. A., Ignatov, A., Liu, L., Mishchenko, M., Eck, T. F., Kucsera, T. L., Giles, D. M., and Kopelevich, O. V.: Ship-based aerosol optical depth measurements in the Atlantic Ocean, comparison with satellite retrievals and GOCART model, Geophys. Res. Lett., 33, L14817, doi:10.1029/2006GL026051, 2006.

Stjern, C. W., Stohl, A., and Kristjánsson, J. E.: Have aerosols affected trends in visibility and precipitation in Europe? J. Geophys. Res., 116, D02212, doi:10.1029/2010JD014603, 2011.

Streets, D. G., Wu, Y., and Chin, M.: Two-decadal aerosol trends as a likely explanation of the global dimming/brightening transition, Geophys. Res. Lett., 33, L15806, doi:10.1029/2006GL026471, 2006.

Tang, I. N.: Chemical and size effects of hygroscopic aerosols on light scattering coefficients, J. Geophys. Res., 101, 1924519250, doi:10.1029/96JD03003, 1996.

Theodosi, C., Grivas, G., Zarmpas, P., Chaloulakou, A., and Mihalopoulos, N.: Mass and chemical composition of sizesegregated aerosols $\left(\mathrm{PM}_{1}, \mathrm{PM}_{2.5}, \mathrm{PM}_{10}\right)$ over Athens, Greece: local versus regional sources, Atmos. Chem. Phys., 11, 1189511911, doi:10.5194/acp-11-11895-2011, 2011.

Tsai, Y. I., Lin, Y. H., and Lee, S. Z.: Visibility variation with air qualities in the metropolitan area of southern Taiwan, Water Air Soil Pollut., 144, 19-40, doi:10.1023/A:1022901808656, 2003.

Tsai, Y. I., Kuo, S. C., Lee, W. J., Chen, C. L., and Chen, P. T.: Long-term visibility trends in one highly urbanized, one highly industrialized, and two rural areas of Taiwan, Sci. Total Environ., 382, 324-341, doi:10.1016/j.scitotenv.2007.04.048, 2007.

van Aardenne, J. A., Dentener, F. J., Olivier, J. G. J., Klein Goldewijk, C. G. M., and Lelieveld, J.: A $1^{\circ} \times 1^{\circ}$ resolution data set of historical anthropogenic trace gas emissions for the period 1890-1990, Global Biogeochem. Cy., 15, 909-928, doi:10.1029/2000GB001265, 2001.

van Beelen, A. J. and van Delden, A. J.: Cleaner air brings better views, more sunshine and warmer summer days in the Netherlands, Weather, 67, 21-25, doi:10.1002/wea.854, 2012.

Vautard, R., Yiou, P., and Oldenborgh, G.: Decline of fog, mist and haze in Europe over the past 30 years, Nat. Geosci., 2, 115-119, doi:10.1038/ngeo414, 2009.

Vestreng, V., Myhre, G., Fagerli, H., Reis, S., and Tarrasón, L.: Twenty-five years of continuous sulphur dioxide emission reduction in Europe, Atmos. Chem. Phys., 7, 3663-3681, doi:10.5194/acp-7-3663-2007, 2007.

Vestreng, V., Ntziachristos, L., Semb, A., Reis, S., Isaksen, I. S. A., and Tarrasón, L.: Evolution of $\mathrm{NO}_{x}$ emissions in Europe with focus on road transport control measures, Atmos. Chem. Phys., 9, 1503-1520, doi:10.5194/acp-9-1503-2009, 2009.

Vrekoussis, M., Richter, A., Hilboll, A., Burrows, J. P., Gerasopoulos, E., Lelieveld, J., Barrie, L., Zerefos, C., and Mihalopoulos, N.: Economic crisis detected from space: Air quality observations over Athens, Greece, Geophys. Res. Lett., 40, 458-463, doi:10.1002/grl.50118, 2013.

Wan, J. M., Lin, M., Chan, C. Y., Zhang, Z. S., Engling, G., Wang, X. M., Chan, I. N., and Li, S. Y.: Change of air quality and its impact on atmospheric visibility in central-western 
Pearl River Delta, Environ. Monit. Assess., 172, 339-351, doi:10.1007/s10661-010-1338-2, 2011.

Wang, K., Dickinson, R. E., and Liang, S.: Clear sky visibility has decreased over land globally from 1973 to 2007, Science, 323, 1468-1470, doi:10.1126/science.1167549, 2009.

Wang, K. C., Dickinson, R. E., Su, L., and Trenberth, K. E.: Contrasting trends of mass and optical properties of aerosols over the Northern Hemisphere from 1992 to 2011, Atmos. Chem. Phys., 12, 9387-9398, doi:10.5194/acp-12-9387-2012, 2012.

Wild, M.: Global dimming and brightening: A review, J. Geophys. Res., 114, D00D16, doi:10.1029/2008JD011470, 2009.

World Meteorological Organization: The WMO Automatic Digital Barometer inter comparison, edited by: van der Meulen, J. P., Instrument and Observing Methods Report No. 46, WMO/TDNo.474, Geneva, 1992.
Wu, J., Fu, C., Zhang, L., and Tang, J.: Trends of visibility on sunny days in China in the recent 50 years, Atmos. Environ., 5, 339346, doi:10.1016/j.atmosenv.2012.03.037, 2012.

Zhao, P., Zhang, X., Xu, X., and Zhao, X.: Long-Term Visibility Trends and Characteristics in the Region of Beijing, Tianjin, and Hebei, China, Atmos. Res., 101, 711-718, doi:10.1016/j.atmosres.2011.04.019, 2011.

Zhao X., Chan, P., and NOAA CDR Program: NOAA Climate Data Record (CDR) of AVHRR Daily and Monthly Aerosol Optical Thickness over Global Oceans, Version 2.0. AOT1, NOAA National Centers for Environmental Information, doi:10.7289/V5SB43PD, 2014. 